\title{
Article \\ Comfort of Domestic Water in Residential Buildings: Flow, Temperature and Energy in Draw-Off Points: Field Study in Two Danish Detached Houses
}

\author{
Anna Marszal-Pomianowska ${ }^{1, *(\mathbb{D})}$, Rasmus Lund Jensen ${ }^{1} \mathbb{D}^{\mathbb{D}}$, Michal Pomianowski ${ }^{1}$, Olena Kalyanova Larsen ${ }^{1}$, \\ Jacob Scharling Jørgensen ${ }^{2}$ and Sofie Sand Knudsen ${ }^{3}$ \\ 1 Department of the Built Environment, Aalborg University, 9200 Aalborg, Denmark; rlje@build.aau.dk (R.L.J.); \\ mzp@build.aau.dk (M.P.); ok@build.aau.dk (O.K.L.) \\ 2 Frandsen \& Søndergaard Rådgivende Ingeniørfirma, 9200 Aalborg, Denmark; jsj@frandsen-sondergaard.dk \\ 3 Akademiingeniør Svend Poulsen A/S, 9500 Hobro, Denmark; sofie@svendpoulsen.dk \\ * Correspondence: ajm@build.aau.dk
}

check for updates

Citation: Marszal-Pomianowska, A.; Jensen, R.L.; Pomianowski, M.;

Larsen, O.K.; Jørgensen, J.S.;

Knudsen, S.S. Comfort of Domestic

Water in Residential Buildings: Flow,

Temperature and Energy in Draw-Off

Points: Field Study in Two Danish

Detached Houses. Energies 2021, 14,

3314. https://doi.org/10.3390/

en14113314

Academic Editor: Francesco Nocera

Received: 4 May 2021

Accepted: 29 May 2021

Published: 4 June 2021

Publisher's Note: MDPI stays neutral with regard to jurisdictional claims in published maps and institutional affiliations.

Copyright: (c) 2021 by the authors. Licensee MDPI, Basel, Switzerland. This article is an open access article distributed under the terms and conditions of the Creative Commons Attribution (CC BY) license (https:// creativecommons.org/licenses/by/ $4.0 /)$.

\begin{abstract}
There is very little knowledge on the occupant actual hot water comfort (temperature and flow), usage practice, and routines (temporal and spatial distribution of hot water usage in a household). This paper describes the results from the total and hot water measurements in two Danish detached houses. The results show that, at the draw-off points, the temperature of $55^{\circ} \mathrm{C}$ is never asked by the occupants, not even in the kitchen sink. The domestic water temperature differentiates depending on the function of the draw-off point, with the shower and kitchen taps being most energy- and water-intense. They constitute around $90 \%$ of the hot water use in the house. Shower units on average demand for highest temperature (i.e., $35.5^{\circ} \mathrm{C}$ to $40.4{ }^{\circ} \mathrm{C}$ ). Hand washing operates, on average, at temperature between $20.5^{\circ} \mathrm{C}$ to $26.5^{\circ} \mathrm{C}$. Average water temperature at the taps located in utility room varies between $23{ }^{\circ} \mathrm{C}$ to $26^{\circ} \mathrm{C}$. These in-depth insight in the total and hot water use in two new-built low energy houses, can a) help building professionals designing more efficient hot water installations; b) enhance the research work on energy flexibility buildings by providing knowledge on most energy-intensive draw-off points; and c) facilitate district heating professionals in improving the network performance.
\end{abstract}

Keywords: domestic water comfort; water flow; temperature measurement; energy use for hot water; hot water spatial distribution in residential buildings; hot water load profiles

\section{Introduction}

The energy reduction initiatives were and still are a cornerstone in the transition towards fossil-free energy systems. As the building sector is responsible for $30 \%$ of the worldwide energy use and $40 \%$ of the global $\mathrm{CO}_{2}$ emissions [1], a great deal of efforts was/is dedicated to the improvements of buildings' energy performance. Energy in buildings is used for heating up the spaces and domestic water, for cooling the spaces, ventilation, lighting, and other services, such as energy input to appliances [2]. In cold climates, the heating need is the major part of total energy use in building sector. During the last decades, the energy efficiency actions (e.g., tightening the energy frames and/or making stricter the regulations for air tightness and thermal characteristics of building envelope and energy performance of heating, ventilation, and air conditioning) aimed primarily to reduce the energy use for space heating $(\mathrm{SH})$. These measures have been efficient and $\mathrm{SH}$ decreased (e.g., in Denmark, the final energy consumption per $\mathrm{m}^{2}$ for heating the dwellings dropped by $25 \%$ since 1990 [3]).

The energy use for production and distribution of the domestic hot water (DHW) has been overlooked when designing the energy efficiency strategies. In consequence, it stayed constant when compared to the decrease of energy use for space heating $(\mathrm{SH})$, however, 
its share in total energy use increased significantly. Pomianowski et al. [4] highlighted that the process of tightening building legislations changed the outlook of total energy use in residential buildings in Denmark, France, and Spain. In these countries, the share of final energy use for production of DHW in buildings constructed in 1940s or 1950s is between $5 \%$ to $10 \%$, while, for the nearly zero energy buildings (NZEBs) and recently built energy-efficient dwellings, the DHW share can reach up to $40 \%$.

The energy use for DHW is related to the characteristics of building occupants, in particular their number, comfort preferences and sequence of practices [5-8]. The energy use for DHW is also influenced by the requirements for personal hygiene, life style, and comfort expectations. Due to increase in populations' requirements for these parameters (i.e., more frequent and longer showers, shorter waiting time for hot water delivery at the tap), the annual DHW consumption per capita in Denmark rose from $10 \mathrm{~m}^{3} /$ year to around $15 \mathrm{~m}^{3}$ /year between 1990 to 2009 [9]. The increased tendency was also noticed in Australia [10] and is expected in other developing and developed countries.

The energy used for preparation of DHW, among others, depends on the amount of used water (flow) and on the hot water temperature. In Denmark, a fixed annual DHW usage of $250 \mathrm{~L} / \mathrm{m}^{2}$ of heated area (with maximum of $60 \mathrm{~m}^{3}$ per year) is applied for energy performance calculations in all residential buildings [11]. According to the review by Fuentes et al. [6], the design hot water temperature for devices producing hot water in Europe is $55^{\circ} \mathrm{C}$, in Canada and USA is $57.3 \pm 3{ }^{\circ} \mathrm{C}$, in Japan is $\leq 65^{\circ} \mathrm{C}$, and, in Australia and New Zealand, there is no limitations for maximum. The temperature level above $50^{\circ} \mathrm{C}$ is primarily set due to hygienic reasons and elimination of Legionella bacteria from water heating devices. These rigid requirements, which define the DHW usage in a function of building area and with constant usage temperature, are understandable when performing the energy compliance calculation of a building or sizing of the DHW production units. However, there is very little knowledge on the occupants' actual domestic water comfort (i.e., temperature and flow), consumption practice, and routines (i.e., temporal and spatial distribution of water consumption in a household). This knowledge would be very helpful in design of efficient DHW installations and in estimations of the actual energy use in a building, and thereby, narrowing the energy performance gap. This paper aims to contribute to the knowledge on real comfort of domestic water by describing results from high resolution DHW measurements in two energy-efficient houses located in Denmark. Thereby, this paper demonstrates the real-life DHW draw-off schedule (i.e., water flow, temperature, duration, and frequency of tapings) for every tap in the house, thus providing in-depth understanding of spatial and temporal distribution of energy use for DHW in households.

\section{Literature}

The presented literature review comprises only the publications related to the DHW measurements campaigns. The work on modeling hot water systems in residential building is out of scope.

The measurements of the DHW at consumption side are not wide-spread and common activity. The metering equipment installed in buildings and used for billing does not differentiate between the energy used for space heating and preparation of the DHW. Table 1 presents that there is very few documented campaigns with the aim to investigate the DHW consumption patterns. 
Table 1. Summary of the DHW measurement campaigns.

\begin{tabular}{|c|c|c|c|}
\hline Ref. & Objective of Study & Period & $\begin{array}{c}\text { Building Typology and } \\
\text { Location }\end{array}$ \\
\hline [12] & $\begin{array}{l}\text { Objective is building a } \\
\text { database with more than } 30 \mathrm{~m} \\
\text { data entries of } \\
\text { DHW measurements }\end{array}$ & 1979 to 1987 & $\begin{array}{ll}\text { 1. } & 110 \text { single-family houses } \\
\text { (USA\#1) } \\
\text { 2. } \\
142 \text { residential buildings } \\
\text { (USA\#2) } \\
\text { 3. } \\
74 \text { and } 24 \text { single-family } \\
\text { houses (USA\#3) } \\
\text { 4. } \\
55 \text { residential buildings } \\
\text { (Canada\#1) } \\
\text { 5. } \\
5 \text { apartment complexes } \\
\text { (Canada\#2) }\end{array}$ \\
\hline
\end{tabular}

\begin{tabular}{|c|c|c|c|c|}
\hline [13] & $\begin{array}{l}\text { Objective is to give directions } \\
\text { on the development of a hot } \\
\text { water consumption pattern } \\
\text { used for design of central } \\
\text { DHW system }\end{array}$ & $\begin{array}{l}\text { September } 1990 \text { to } \\
\text { August } 1991\end{array}$ & $\begin{array}{l}4 \text { multifamily buildings } \\
\text { (Greece); in total, } 83 \text { apartment } \\
\text { of household size between } 1 \text { to } \\
7 \text { persons }\end{array}$ & $\begin{array}{l}\text { DHW centrally monitored } \\
\text { at building level with } \\
\text { 1-min intervals, use of } \\
\text { magnetic tapes; manual } \\
\text { readings at apartment level }\end{array}$ \\
\hline [14] & $\begin{array}{l}\text { Objective is to determine } \\
\text { efficiency of current } \\
\text { DHW systems }\end{array}$ & 2000 to 2008 & $\begin{array}{l}13 \text { multifamily buildings } \\
\text { (Denmark); in total, } 1370 \\
\text { apartment units }\end{array}$ & $\begin{array}{l}\text { DHW centrally monitored } \\
\text { at building level in the } \\
\text { with 5-min intervals. }\end{array}$ \\
\hline [15] & $\begin{array}{l}\text { Objective is to provide } \\
\text { information on residential } \\
\text { hot-water usage patterns and } \\
\text { on the DHW consumption } \\
\text { changes after introduction of } \\
\text { the DHW standard in } 1990\end{array}$ & $\begin{array}{c}2007 \text { to } 2009 \\
\text { Measurements } \\
\text { performed over } \\
\text { two-three weeks per } \\
\text { household }\end{array}$ & $\begin{array}{l}74 \text { households of size between } \\
2 \text { to } 5 \text { persons (Canada) }\end{array}$ & $\begin{array}{l}\text { DHW monitored at } \\
\text { production point in each } \\
\text { house with 2-s and, later, } \\
\text { 4-h intervals. } \\
\text { Supplementary } \\
\text { questionnaire given } \\
\text { to occupants }\end{array}$ \\
\hline [16] & $\begin{array}{l}\text { Objective is to investigate user } \\
\text { profiles and to determine } \\
\text { energy demand for DHW }\end{array}$ & $\begin{array}{l}\text { January } 2012 \text { to April } \\
2013 \\
\text { May } 2013 \text { to June } 2014\end{array}$ & $\begin{array}{l}4 \text { apartment complexes } \\
\text { (Finland); } \\
\text { in total, } 182 \text { apartment units } \\
\text { and } 379 \\
\text { occupants routines } \\
\text { are monitored }\end{array}$ & $\begin{array}{l}\text { Measuring resolution } \\
\text { not provided }\end{array}$ \\
\hline [17] & $\begin{array}{l}\text { Objective is to develop a series } \\
\text { of representative DHW draw } \\
\text { profiles at high temporal } \\
\text { resolution for simulating the } \\
\text { performance of solar } \\
\text { thermal systems }\end{array}$ & $\begin{array}{l}\text { November } 2006 \text { to } \\
\text { April } 2007\end{array}$ & $\begin{array}{l}73 \text { single-family houses } \\
\text { (Canada); } \\
\text { household size between } 1 \text { to } 5 \\
\text { persons. }\end{array}$ & $\begin{array}{l}\text { DHW monitored at } \\
\text { production point in each } \\
\text { house with 5-min time } \\
\text { steps with pulse signal of } \\
1 \mathrm{~L}\end{array}$ \\
\hline [18] & $\begin{array}{l}\text { Objective is to investigate user } \\
\text { profiles and to determine } \\
\text { energy demand for DHW }\end{array}$ & $\begin{array}{l}\text { May } 2014 \text { to } \\
\text { February } 2015\end{array}$ & $\begin{array}{l}1 \text { apartment complex (Finland; } \\
\text { in total, } 86 \text { apartment units and } \\
191 \text { occupants routines } \\
\text { are monitored }\end{array}$ & $\begin{array}{l}\text { Monitored data obtained in } \\
\text { hourly time steps; } \\
\text { minimum accuracy } 1 \mathrm{~L}\end{array}$ \\
\hline [19] & $\begin{array}{l}\text { Objective is to develop a } \\
\text { generator of high temporal } \\
\text { resolution hot water profiles }\end{array}$ & July 2014 to June 2015 & $\begin{array}{l}4 \text { dwellings in multi-family } \\
\text { building (Switzerland) }\end{array}$ & $\begin{array}{l}\text { Monitored data obtained as } \\
\text { accumulated values with } \\
\text { accuracy of } 0.25 \mathrm{~L}\end{array}$ \\
\hline [10] & $\begin{array}{l}\text { Objective to investigate the } \\
\text { tendency of total, rainwater, } \\
\text { mains and hot } \\
\text { water consumption }\end{array}$ & $\begin{array}{l}\text { January } 2010 \text { to } \\
\text { January } 2013\end{array}$ & $\begin{array}{l}59 \text { households of size between } \\
1 \text { to } 5 \\
\text { persons (Australia). }\end{array}$ & $\begin{array}{l}\text { Monitored data obtained in } \\
\text { minutely time steps. }\end{array}$ \\
\hline [20] & $\begin{array}{l}\text { Objective is to demonstrate a } \\
\text { high-resolution DHW } \\
\text { measurement set-up }\end{array}$ & $\begin{array}{l}\text { December } 2017 \\
\quad(2 \text { weeks })\end{array}$ & $\begin{array}{l}\text { Detached single-family house } \\
\text { (Denmark) with } 5 \text { persons. }\end{array}$ & $\begin{array}{l}\text { DHW monitored at draw } \\
\text { point level with resolution } \\
\text { of } 2 \mathrm{~Hz} \text { (in total, } \\
9 \text { set-ups installed) }\end{array}$ \\
\hline
\end{tabular}


Becker and Stogsdill [12] reviewed five field studies of DHW consumption conducted in Canada and USA and organized them in a database form. The database complies more than 30 million data entries of DHW usage in residential buildings. The average DHW consumption was calculated to be $238 \mathrm{~L} /$ day per residential unit for weekdays and weekends with peaks over $13 \mathrm{~L} /$ hour in the mornings between 6:00-11:00 a.m. and evenings between 5:00-9:00 p.m. The significantly higher average DHW use compared to European countries could be due to the fact that in USA and Canada dishwashers and washing machines are often connected to hot water installation.

Papakostas et al. [13] presented the DHW draw-off profiles built from the experimental data collected in four multifamily buildings in Greece. The DHW consumption is monitored centrally in every building by flow meter and temperature sensor located at the cold water supply and a second temperature sensors at hot water pipe after the water storage tank. Moreover, every apartment has a manual flow meter. The hourly load profile for an average day is given at the building level and indicates a clear pattern for weekdays and weekends. During the weekday, there is a "small" peak at 1:00 p.m. and a clear evening peak between 8:00-10:00 p.m. The weekend profile has a more even distribution during the day hours with a "small" peak at 6:00 p.m. The results showed that the average DHW consumption is $32.2 \mathrm{~L} /$ day per person, which is then calculated to an energy consumption of $0.83 \mathrm{kWh} /$ day per person (with assumption of hot water temperature of $42^{\circ} \mathrm{C}$ ). Finally, the measurements of Papakostas et al. revealed that the average daily DHW usage per person decreases with the increase of family size.

Bøhm [14] measured the energy demand for production and circulation of the DHW in 13 multifamily buildings. This building typology is characterized by extensive installations for DHW circulations, which is a consequence of regulation for waiting time for hot water being set for max. $10 \mathrm{~s}$ at each water tap in the building. Therefore, Bøhm selected this typology for investigations. The consumption of cold water for DHW varies between 1.4 and $4.3 \mathrm{~m}^{3}$ /month per apartment. In the multifamily buildings, the circulation losses are between $23 \%$ to $70 \%$. Moreover, the circulation installation influences negatively the cooling of the district heating water (i.e., the temperature difference between supply and return water varies between $19 \mathrm{~K}$ to $45 \mathrm{~K}$ ).

Thomas et al. [15] measured the DHW consumption in 74 Canadian residences. In each house, the flow meter was installed at the pipe supplying cold water to the water heater. Results showed that the average DHW usage has dropped in the past 17 years from $243 \mathrm{~L} /$ day per residential unit to $186 \mathrm{~L} /$ day per residential unit. This is a reduction of $25 \%$. The occupancy level was a significant indicator of daily DHW use. The Canadian and USA standards adopt fewer draws but with larger flow per event (i.e., 6 draws of $41 \mathrm{~L} / \mathrm{draw}$ ) compared to measured 79 draws of $2.7 \mathrm{~L} /$ draw. This study indicates significant discrepancy between standard values and the values provided from the field measurements and that there is lacking knowledge and understanding within the subject. Another conclusion is that occupant behavior and preferences may change considerably in time; therefore, the ongoing intensified monitoring in the field is required.

Ahmed et al. [16] conducted a measuring campaign on 182 Finnish apartments. Measurements were taken at the apartment level in two periods (i.e., 2012 to 2013 and 2013 to 2014). In the first period, DHW consumption was measured on a monthly basis, and in the second period on a daily basis. The objective of the campaign was to determine the DHW profiles, thereby being able to better predict building energy use and to facilitate the design process of DHW installations and/or systems. Measurements indicated average DHW use at $43 \mathrm{~L} /$ day per person.

Edwards et al. [17] measured the DHW consumption at the production point in 73 houses in Canada. In each house, the flow meter was installed at the pipe supplying cold water to the electric-resistance heater, since the volume of DHW water is replaced in the tank by cold make-up water. The results showed the DHW consumption varies between $70 \mathrm{~L} /$ day to $438 \mathrm{~L} /$ day per house with mean value of $189 \mathrm{~L} /$ day and standard deviation of $83 \mathrm{~L} /$ day. Yet, no correlation to the number of occupants was given. Twenty-five percent 
of the houses had an average daily profile characterized as "morning customers" with DHW peak between 7:00-8:00 a.m. Thirty percent of the houses were characterized as "evening customers" with low consumption during morning and daytime, but with peak consumption of almost 30\% of total daily DHW consumption between 7:00-8:00 p.m.

The second campaign conducted in 86 Finnish apartments between May 2014 to February 2015 aimed to determine the hourly DHW profiles for five user groups in order to be able to estimate energy demand for preparation and distribution of DHW [18]. Measurements revealed two peaks during the day (i.e., the morning peak between 7:00-9:00 a.m. and the evening peak between 8:00-10:00 p.m.). In weekends, the morning peak shifted with two hours forward and evening peak occurrence was unchanged compared to weekdays. The average DHW consumption in peak periods and outside peak periods was determined at $3.6 \mathrm{~L} / \mathrm{h}$ hour and $1.5 \mathrm{~L} / \mathrm{h}$, respectively.

Santiago et al. [19] conducted a full year monitoring campaign of domestic hot water in four dwellings in Switzerland. The measurements included two temperature sensors of supply and outlet water from the hot water tank and a flow meter measuring the accumulated water consumption with $0.25 \mathrm{~L}$ resolution. The measurement revealed that hot water consumption per person varied with between 23 to $48 \mathrm{~L} /$ day per person, and the high end values were registered in the 2-person units. In three units, the weekend consumption was higher than during the weekdays.

The monitoring campaign in 59 Australian dwellings investigated the trend of total and hot water consumption in households equipped with rainwater tanks [10]. The 3-years measurements demonstrated that hot water consumption has a seasonal patter with peaks of 59 and $60 \mathrm{~L} /$ day per person in June and August. Over the 3 years, the monthly hot water consumption per household increased from 3200 to $4000 \mathrm{~L}$. The diurnal average hot water profile showed a clear morning peak at 7:00 a.m. of $14 \mathrm{~L} / \mathrm{h}$ per household and an afternoon peak at 6:00 p.m. of $8.5 \mathrm{~L} / \mathrm{h}$ per household. The peak size differed by factor seven between the maximum and minimum users, and the maximum users had additional nighttime peak around midnight.

The first study where the DHW field measurements were conducted at the tap level was by Reference [20]. At each tap in the house, a flow meter was installed at the cold and hot water supply pipe. They recorded the water flow and temperature in $8 \mathrm{~Hz}$ resolution. The quantitative data showed that the length of draws differ between the taps. The showering events had an average duration of $300 \mathrm{~s}$ and the temperature between $37^{\circ} \mathrm{C}$ to $43^{\circ} \mathrm{C}$. In the kitchen, the average event had a length of $20 \mathrm{~s}$. The $80 \%$ of the events in the kitchen were shorter than $30 \mathrm{~s}$. This indicated that users used the kitchen tap primarily for filling the kettle, washing hands, and rinsing vegetables/fruits, which are characterized by short use of water. The temperature of tapped water at the kitchen sink ranged between $40{ }^{\circ} \mathrm{C}$ to $45^{\circ} \mathrm{C}$ for more than $60 \%$ of the events.

In the majority of described measurement campaigns, the DHW consumption and load patterns were monitored at the household level. Therefore, the knowledge on the distribution of DHW usage between the draw points in the household is quite limited. To fill in this gap, two approaches were applied:

- measurement of the water flow per end-use and taping temperature inferred from standards and/or statistics [21-25], and

- measurement of the energy use for DHW per unit (i.e., household, building) with characteristics on end-use draw events (i.e., volume, flow rate, duration, and frequency) derived from other scientific references $[5,26]$.

The models are often burdened with many assumptions (e.g., constant water flow at the particular end-uses, constant temperature of $55^{\circ} \mathrm{C}$ of the hot water at individual end-uses) and the actual understanding of energy use for DHW of various end-uses is not well developed. The knowledge on the spatial distribution of the DHW usage (i.e., the flow and the temperature) in the system is essential information for efficient design and operation of heating installations in existing and new-built buildings, and thereby the reduction of the environmental footprints of the building sector. Moreover, this information 
is also incredibly valuable for the district heating $(\mathrm{DH})$ networks and their transformation towards 4 th generation $\mathrm{DH}$. The future $\mathrm{DH}$ grids are aimed to operate on low and ultra-low supply temperatures, using intermittent energy sources, such as solar and wind energy, and, therefore, needs an in-depth understanding on their demand side, which can facilitate their smooth transformation and cost-optimal network operation.

\section{Research Aims}

The share of energy use for preparation and distribution of DHW constitutes a big piece of the total energy use in a building. As pointed out by Pomianowski et al. [4], this share, among others, depends on the year of construction of a building and its location. The literature review of the conducted DHW measurement campaigns indicated that the energy use for DHW is related to the household size and national characteristics. Moreover, the review demonstrated that the current understanding of the actual DHW consumption (i.e., water and energy) is primarily limited to the residential unit level (i.e., apartment in multifamily block or single-family house). There is lack of detailed knowledge of real-life characteristics (i.e., water flow, temperature, events duration, and frequency of use) of different water draw points located within the households and how these features vary in time. Moreover, the field studies delivered fragmented knowledge that, in many cases, does not represent the up-to-date changes in hygiene requirements. In response, this paper contributes to closing this knowledge gap by presenting results from a field study, where the flow and the temperature are monitored with the resolution of $8 \mathrm{~Hz}$ at all water draw points in two new-built energy-efficient houses. The measurement results are translated into following contributions:

1. Spatial and temporal distribution of domestic water usage in two detached houses. The novelty is in providing the in-depth knowledge on the temperature distribution, duration of water tapings, water consumption, and used energy at each draw-off point using only high granularity monitored data without assistance of modeling work or values from standards. The quantitative water data are augmented with few socioeconomic characteristics of the occupants (e.g., gender, age, and employment), their daily routines, and details on hot and cold water installation characteristics (e.g., pipe distribution in the house and pipe properties).

2. Evaluation of the measured data against the standard values of DHW consumption used in the design of DHW installation or in energy software compliance tools.

The obtained results are intended to get a better and updated understanding of how the DHW is used in the residential single-family houses, particularly what the temperature and flow characteristics of each water draw-off point are. Thereby, the spatial and temporal distribution of energy use for DHW low-energy buildings is drawn.

\section{Materials and Methods}

This section is divided into three subsections, each corresponding to the particular part of the methodology. The first section presents two case buildings, the second one describes the equipment used in the measurement campaign, and the third one outlines the measurement set-up.

\subsection{Buildings}

The measurements were conducted in two detached single-family houses located, respectively, in northern Denmark (House 1) and in central Denmark (House 2) in the cities of a similar size and socio-cultural characteristics. Both locations have similar weather conditions. Both houses represent the "typical" houses [27] built after 2010 and are occupied by a family. The family in House 1 represents the typical " $2+2$ " working family. The family in House 2 represents the young working couple that is involved in many activities outside their home. Figure 1 presents the layout of each case house, as well as indication of the household size and configuration. Table 2 summarizes the key information on the case houses and occupants. The following paper presents the measurement results for 
draw-off points excluding measurements at the washing machine and dishwasher that are connected only to cold water. The metering equipment was first installed in House 1 and afterwards moved to House 2. The metering periods were selected for the analysis as the quality of the data was the best during these weeks, and they represent similar seasons during the year (i.e., transition periods).
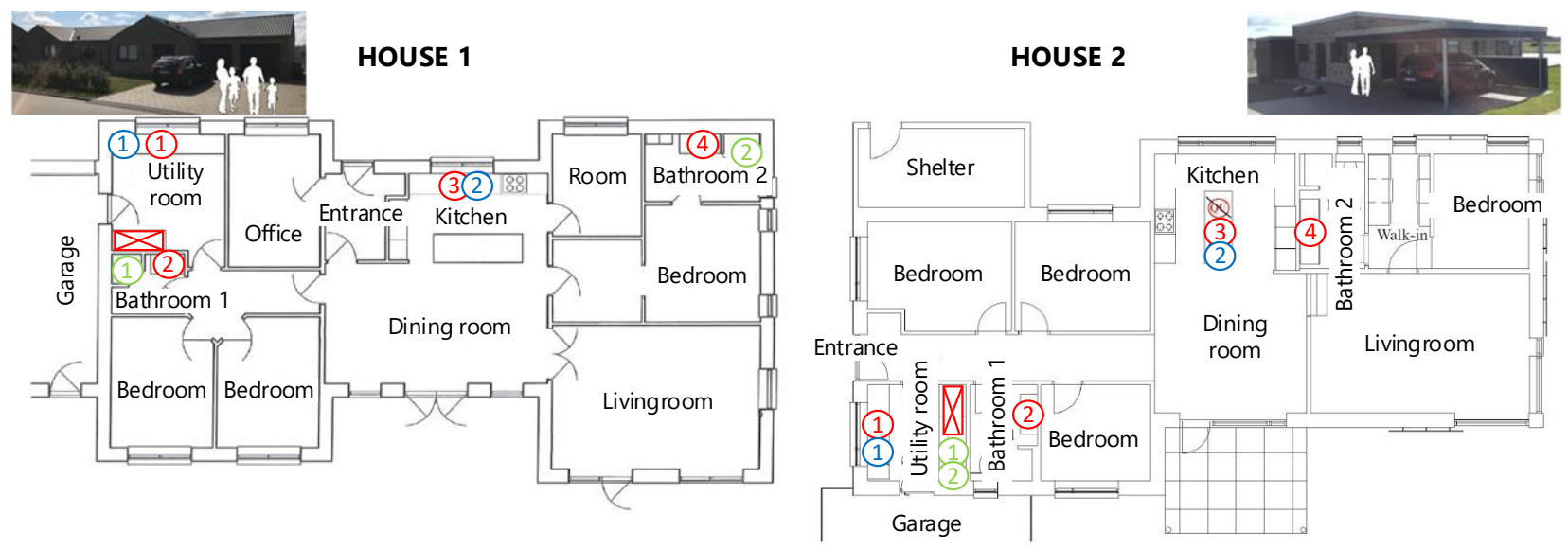

Bathroom or kitchen sink (CW \& HW)

Shower

Washing machine (1) or dishwasher (2) (CW)

DHW producton/distribution point

Figure 1. Layout of the case buildings and numbering of the tap locations.

Table 2. Specification of the case buildings.

\begin{tabular}{|c|c|c|c|c|c|c|}
\hline Case & Area $\left(m^{2}\right)$ & $\begin{array}{c}\text { No. of } \\
\text { Showers }\end{array}$ & $\begin{array}{l}\text { No. of } \\
\text { Sinks }\end{array}$ & $\begin{array}{c}\text { Construction } \\
\text { Year }\end{array}$ & $\begin{array}{c}\text { No. of } \\
\text { Occupants }\end{array}$ & $\begin{array}{c}\text { Metering } \\
\text { Period }\end{array}$ \\
\hline House 1 & 195 & 2 & 4 & $\begin{array}{c}2013 \\
(\mathrm{BR} 10)^{1}\end{array}$ & 4 & $\begin{array}{c}\text { September } \\
\text { to October } \\
2018 \\
\text { (7 weeks) }\end{array}$ \\
\hline House 2 & 160 & 2 & 4 & $\begin{array}{c}2017 \\
(\mathrm{BR} 15)^{1}\end{array}$ & 2 adults & $\begin{array}{l}\text { March to } \\
\text { April } 2019 \\
\text { (4 weeks) }\end{array}$ \\
\hline
\end{tabular}

1.(valid building code).

In House 1, the DHW is produced in instantaneous heat exchange unit where the source of the heat is the DH network. House 2 is also connected to DH grid. This case house is equipped with a compact heat pump, which is a complementary ventilation and heating system providing the house with ventilation, heat recovery, and production of DHW. The DH is used to heat up the DHW as secondary source, only if the heat pump cannot meet the demand.

DHW installation in both case houses is made from PEX pipes and a manifold in star plumbing circuit. The DHW pipe network is located above the ground deck insulation in order to utilize the distribution heat losses for additional space heating. The diameter of the pipes is $\varnothing 15$. Figure 2c,d present the technical closets in case houses, together with the installed measurements equipment. 

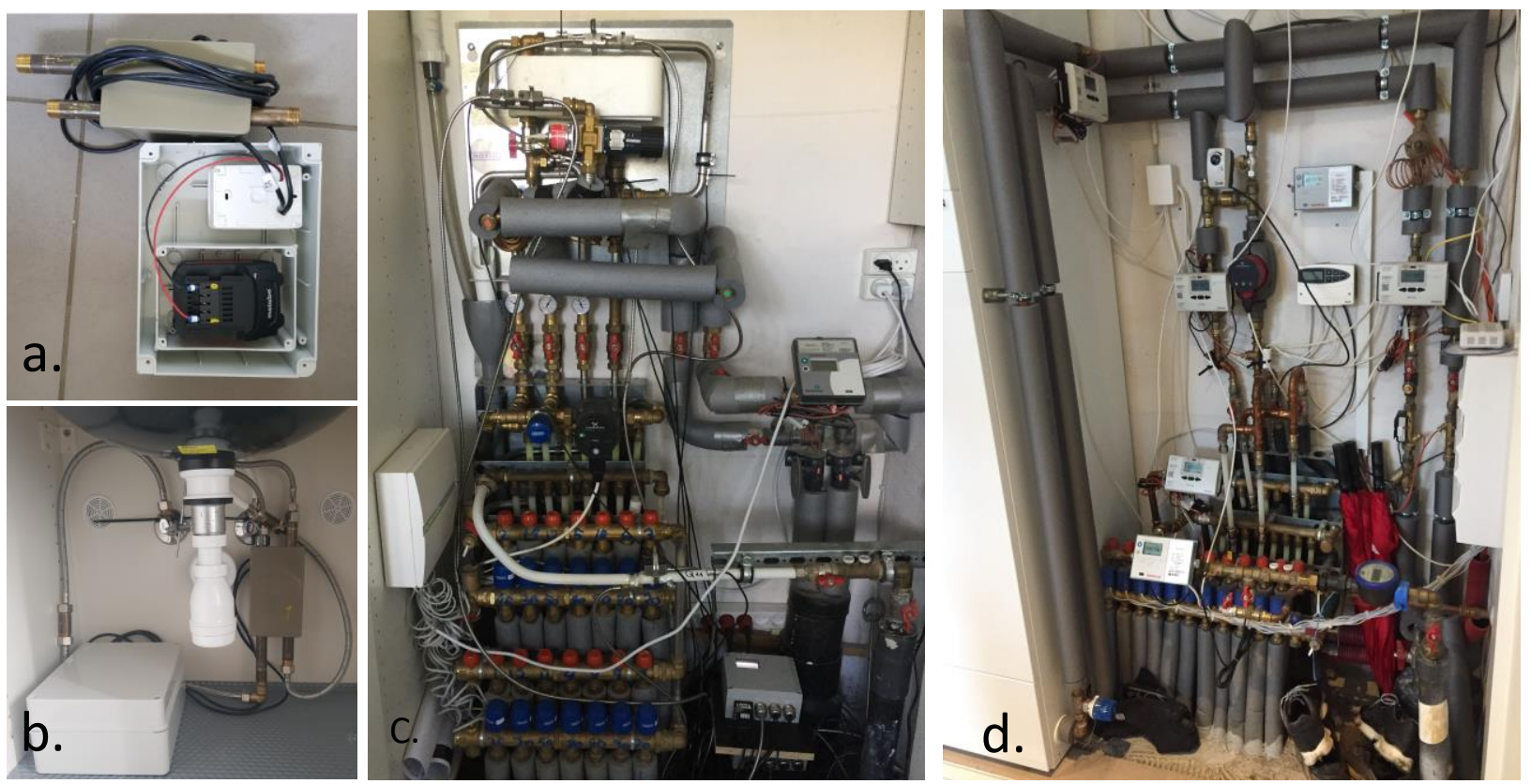

Figure 2. Flowmeters set-up layout (a). Flow meters installed at the kitchen sink in House 1 (b). The technical closet with the measurement equipment in House 1 (c), House 2 (d).

\subsection{Occupants' Practices and Routines Around Domestic Water Use}

The family living in House 1 consists of two adults (male and female) working fulltime and two children (age 6 and 9 years, male). On weekdays, the mornings start at approximately 6:30 a.m., where both adults take a shower, in turn, in Bathroom 2 . For the children, the morning routine includes basic hygiene tasks, such as brushing teeth and face/hand washing. The use of the kitchen in the mornings is limited to basic cooking, preparing lunch-boxes, and mild clean-up. The family leaves the house at approximately 7:30 a.m. and returns home after approximately 8 to $9 \mathrm{~h}$. Both children take part in afterschool activities ( 3 out of 5 weekdays); thus, only half of the household is at home on those afternoons. The weekday evening routine includes cooking and cleaning in the kitchen. At least a few times a week, the children are put into a temporary 60-L bathtub, one at a time before bedtime. Typically, the evening hygiene for adults does not include a shower.

On the weekends, the mornings in House 1 start at approximately 8:00 a.m. The use of $\mathrm{DHW}$, in this case, is more distributed over the day: use of the shower and the bathtub can take place at any time of the day, cleaning activities vary a lot from weekend to weekend and the same is true for the cooking. There are many weekends when the family is only partly at home or not at all.

In general, House 1 is often visited by family and has numerous scheduled play dates for children, both on weekdays and weekends. Bathroom 2 is typically used by the adults in the family and sometimes by children for shower. Bathroom 1 is used by children and guests. The kitchen sink is also frequently used for washing hands; meanwhile, the sink in the utility room is not used very often. The dishwasher is frequently used for all types of dishes. Very few dishes are cleaned manually. The family owns a 200-L fish tank, which is maintained via cold water taps in Bathroom 2.

House 2 is occupied by a young couple (male and female) with full-time jobs. The weekday morning routine for the couple starts at approximately 6:30 a.m., but, contrary to House 1, only one member of the household takes a morning shower. The number of showers in this household is, in general, greatly reduced due to daily fitness activity. In this household, the use of the kitchen in the mornings is at its minimum. The couple leaves their home early in the morning and returns home late in the evening, often at the dinner time. Use of DHW in the evening includes cooking and moderate cleaning activity. 
The couple is engaged in numerous activities besides their jobs, which explains late arrival home and frequent absence from home in the weekends. In general, the couple uses Bathroom 2 in their daily life to reduce unnecessary cleaning. The utility room is rarely used for specific cleaning tasks. It must be mentioned that a Quooker (tap that only dispenses boiling water) is installed in House 2 in the kitchen.

\subsection{Measurement}

The measurement set-up installed in each house consists of two parts: (i) the high resolution measurements of flow and temperature of cold and hot water at each draw point in the house and (ii) at the energy meters at the DHW production point in the technical closet. Moreover, the temperature and flow of the cold water supply to the washing machine and dishwasher were measured. The showers in House 1 are installed with the built-in mixing battery, and separate measurements of cold and hot water were impossible. Therefore, only the total water flow, without differentiation between hot and cold water, and the water temperature after the mixing battery are measured. In House 2, it was not feasible to place the measuring equipment after the mixing battery. Therefore, the sensors were moved to the technical closet and placed close the manifold. Figure 1 displays the location of draw points/sensors and DHW production/distribution point in both case houses.

The measurements at the draw points are conducted with the flowmeters set-up presented in Figure 2a. It includes a box with two Huba flow sensor type 236 [28] (1 for hot and 1 for cold water), as well as a waterproof box with Arduino micro board and power supply. Huba flow sensors require direct installation in the pipes, and they measure voltage output that is later converted to SI units. The flowmeter set-up was developed at Aalborg University and tested in the measurements campaign in 2017 [20]. The data were collected with the resolution of $8 \mathrm{~Hz}$ and transferred via WiFi to the server every $15 \mathrm{~min}$. In this way, the risk for gaps in the time series was reduced. Figure $2 b$ shows the set-up installed at the kitchen sink in House 1.

The measurements in the technical closets include placement of the Ultrasonic Flow Transmitters (KATflow) [29] with PT100 sensor on the main DHW pipes delivering water to the manifold. KATflow meter is a clamp mounted externally on the pipes. In House 1, the KATflow meters are also located at the DH supply and return pipes to the instantaneous heat exchanger.

In order to calculate the flow and the temperature of water at each draw point, Equations (1) and (2) were used:

$$
\begin{gathered}
\mathrm{m}_{\text {mix }}=\mathrm{m}_{\mathrm{CW}}+\mathrm{m}_{\mathrm{HW}}, \\
\mathrm{t}_{\text {mix }}=\left(\mathrm{m}_{\mathrm{CW}} \cdot \mathrm{c}_{\mathrm{p}, \mathrm{CW}} \cdot \mathrm{t}_{\mathrm{CW}}+\mathrm{m}_{\mathrm{HW}} \cdot \mathrm{c}_{\mathrm{p}, \mathrm{HW}} \cdot \mathrm{t}_{\mathrm{HW}}\right) /\left(\mathrm{m}_{\mathrm{CW}} \cdot \mathrm{c}_{\mathrm{p}, \mathrm{CW}}+\mathrm{m}_{\mathrm{HW}} \cdot \mathrm{c}_{\mathrm{p}, \mathrm{HW}}\right), \\
\mathrm{E}_{\mathrm{ev}}=\mathrm{m}_{\text {mix }, \mathrm{ev}} \cdot \mathrm{c}_{\mathrm{p}, \mathrm{ev}} \cdot\left(\mathrm{t}_{\mathrm{ev}}-20\right),
\end{gathered}
$$

where $\mathrm{m}$ is water mass $(\mathrm{kg}), \mathrm{cp}$ is specific heat capacity $\left(\mathrm{kJ} / \mathrm{kg}^{\circ} \mathrm{C}\right), \mathrm{t}$ is temperature $\left({ }^{\circ} \mathrm{C}\right)$, and $\mathrm{E}$ is energy $(\mathrm{kJ})$. The energy used to heat up the water was also calculated for each draw point using Equation (3). The calculations are performed per water taping and with the assumption that the total water consumption in the event is heated from $20{ }^{\circ} \mathrm{C}$ to the mean temperature of the event. Therefore, the calculated value is just an estimate, which is used to give an insight in the distribution of energy between draw points in the household rather than an exact number of used $\mathrm{kJ}$.

\section{Results}

\subsection{Duration, Temperature and Energy of Domestic Water at Each Draw-Off Point}

This part presents a simple statistical analysis of the monitoring data from both houses. Each draw-off point is analyzed separately. All water tapings were used to draw the cumulative frequency distribution curves for duration and temperature, as well 
as the domestic water (cold, hot, and total) distribution between the draw-off points in each house.

According to Table 3, in House 1, the kitchen sink is by far the most frequently used draw-off point with an average number of 32.7 daily water tapings, which constitute $70 \%$ of all water draw events (not energy use) in the house. The hand washing sinks in both bathrooms have daily usage of ca. 5 water tapings per day. The shower in bathroom 1 is rarely used, which corresponds well with the knowledge on occupants daily routines during the monitoring periods (i.e., taking showers after swimming lessons).

Table 3. Overview of water draw events at every tap in House 1 and 2.

\begin{tabular}{lllllll}
\hline No. of Draws & $\begin{array}{l}\text { Kitchen } \\
\text { Sink }\end{array}$ & $\begin{array}{l}\text { HW } \\
\text { Bath 1 }\end{array}$ & $\begin{array}{l}\text { Shower } \\
\text { Bath 1 }\end{array}$ & $\begin{array}{l}\text { HW } \\
\text { Bath 2 }\end{array}$ & $\begin{array}{l}\text { Shower } \\
\text { Bath 2 }\end{array}$ & $\begin{array}{l}\text { HWtility } \\
\text { Room } \\
\text { Rom }\end{array}$ \\
\hline $\begin{array}{l}\text { House 1 } \\
\text { Daily }\end{array}$ & 32.7 & 5.4 & 0.1 & 5.1 & 1.6 & 2.0 \\
$\begin{array}{l}\text { Total (21 days) } \\
\text { House 2 }\end{array}$ & 687 & 114 & 2 & 108 & 34 & 42 \\
$\begin{array}{l}\text { Daily } \\
\text { Total (28 days) }\end{array}$ & 306 & 27 & - & 12.4 & 0.8 & 0.5 \\
\hline
\end{tabular}

In House 2, the use of draw-off points has other distribution; see Table 3. The handwashing sink in bathroom 2, located close to the master bedroom, and the kitchen sink constitute, respectively, $49 \%$ and $43 \%$ of all tapings (not energy use) in the house. The remaining draw-off points during the monitoring period of 28 days are used less than $10 \%$. The daily use of shower of 0.8 indicates that the house might be occupied by one and not two persons. The reason for that is the lifestyle of the occupants, who are actively involved in many sport activities and often take a shower after training, thus being outside of their own home.

Figure 3 demonstrates the longest water taping in Houses 1 and 2 belongs to shower activity. The duration is between $4-13 \mathrm{~min}$. The S-shape of the cumulative curve indicates normal distribution of shower event lengths with mean duration of 7-8 min per shower. Almost all other water tapings from remaining draw-off points last below 2 min and have steep shape in the first seconds of duration, indicating that $80 \%$ of them are below $30 \mathrm{~s}$. Water tapings from kitchen sink and hand washing are dominated by very short events where, in $90 \%$ of cases, duration is less than $15 \mathrm{~s}$ and $20 \mathrm{~s}$ for, respectively, House 1 and 2 . These very short water draws explain the necessity for high measuring and logging resolution if the thorough understanding of the DHW usage is to be drawn.

Figure 4 compares the cumulated water temperature for both buildings and all monitored draw-off points. The majority of the short water tapings, especially from hand washing points (HW bath), have relatively low water temperature that for approximately $80 \%$ of time is below $27^{\circ} \mathrm{C}$. Showering temperature is significantly higher and is in the same interval in both buildings, between 38 and $42{ }^{\circ} \mathrm{C}$. The distribution of water temperature in the kitchen tap differs between the monitored buildings. This variation clearly indicates that occupants in the monitored buildings have different water temperature preferences for washing dishes. It could also be an indication that, in House 1, the dishes requiring high temperature to remove the fat are washed in the dishwasher, and, in House 2, the occupants do these dishes by hand. However, this is just a hypothetical explanation that must be validated by the qualitative data (e.g., interviews with occupants on the dishwashing practices). 

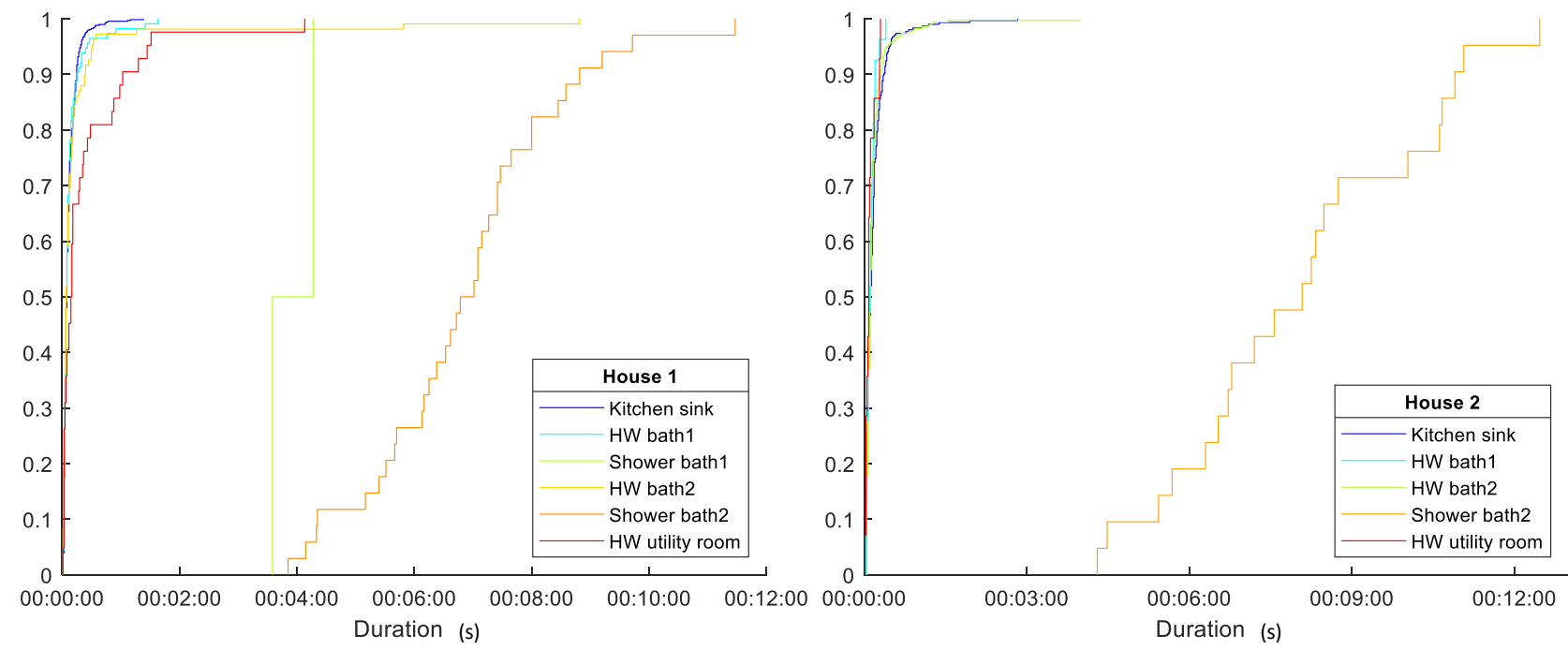

\begin{tabular}{r|cccc} 
Draw off point & Min (s) & Median (s) & Mean (s) & Max (s) \\
\hline Kitchen sink & $0^{\prime} 01^{\prime \prime}$ & $0^{\prime} 05^{\prime \prime}$ & $0^{\prime} 07^{\prime \prime}$ & $1^{\prime} 23^{\prime \prime}$ \\
HW bath 1 & $0^{\prime} 01^{\prime \prime}$ & $0^{\prime} 05^{\prime \prime}$ & $0^{\prime} 08^{\prime \prime}$ & $1^{\prime} 38^{\prime \prime}$ \\
Shower bath 1 & $3^{\prime} 35^{\prime \prime}$ & $3^{\prime} 40^{\prime \prime}$ & $3^{\prime} 56^{\prime \prime}$ & $4^{\prime} 17^{\prime \prime}$ \\
HW bath 2 & $0^{\prime} 01^{\prime \prime}$ & $0^{\prime} 04^{\prime \prime}$ & $0^{\prime} 15^{\prime \prime}$ & $8^{\prime} 49^{\prime \prime}$ \\
Shower bath 2 & $3^{\prime} 51^{\prime \prime}$ & $6^{\prime} 50^{\prime \prime}$ & $6^{\prime} 52^{\prime \prime}$ & $11^{\prime} 28^{\prime}$ \\
HW utility room & $0^{\prime} 01^{\prime \prime}$ & $0^{\prime} 09^{\prime \prime}$ & $0^{\prime} 24^{\prime \prime}$ & $4^{\prime} 08^{\prime \prime}$
\end{tabular}

\begin{tabular}{r|cccc} 
Draw off point & Min (s) & Meadian (s) & Mean (s) & Max (s) \\
\hline Kitchen sink & $0^{\prime} 01^{\prime \prime}$ & $0^{\prime} 07^{\prime \prime}$ & $0^{\prime} 10^{\prime \prime}$ & $2^{\prime} 50^{\prime \prime}$ \\
HW bath 1 & $0^{\prime} 02^{\prime \prime}$ & $0^{\prime} 06^{\prime \prime}$ & $0^{\prime} 07^{\prime \prime}$ & $0^{\prime} 24^{\prime \prime}$ \\
HW bath 2 & $0^{\prime} 03^{\prime \prime}$ & $0^{\prime} 07^{\prime \prime}$ & $0^{\prime} 10^{\prime \prime}$ & $3^{\prime} 58^{\prime \prime}$ \\
Shower bath 2 & $4^{\prime} 18^{\prime \prime}$ & $8^{\prime} 01^{\prime \prime}$ & $8^{\prime} 01^{\prime \prime}$ & $12^{\prime} 28^{\prime \prime}$ \\
HW utility room & $0^{\prime} 01^{\prime \prime}$ & $0^{\prime} 05^{\prime \prime}$ & $0^{\prime} 06^{\prime \prime}$ & $0^{\prime} 18^{\prime \prime}$
\end{tabular}

Figure 3. Cumulated frequency of duration of water draw events for all monitored taps. HW—hand washing point.
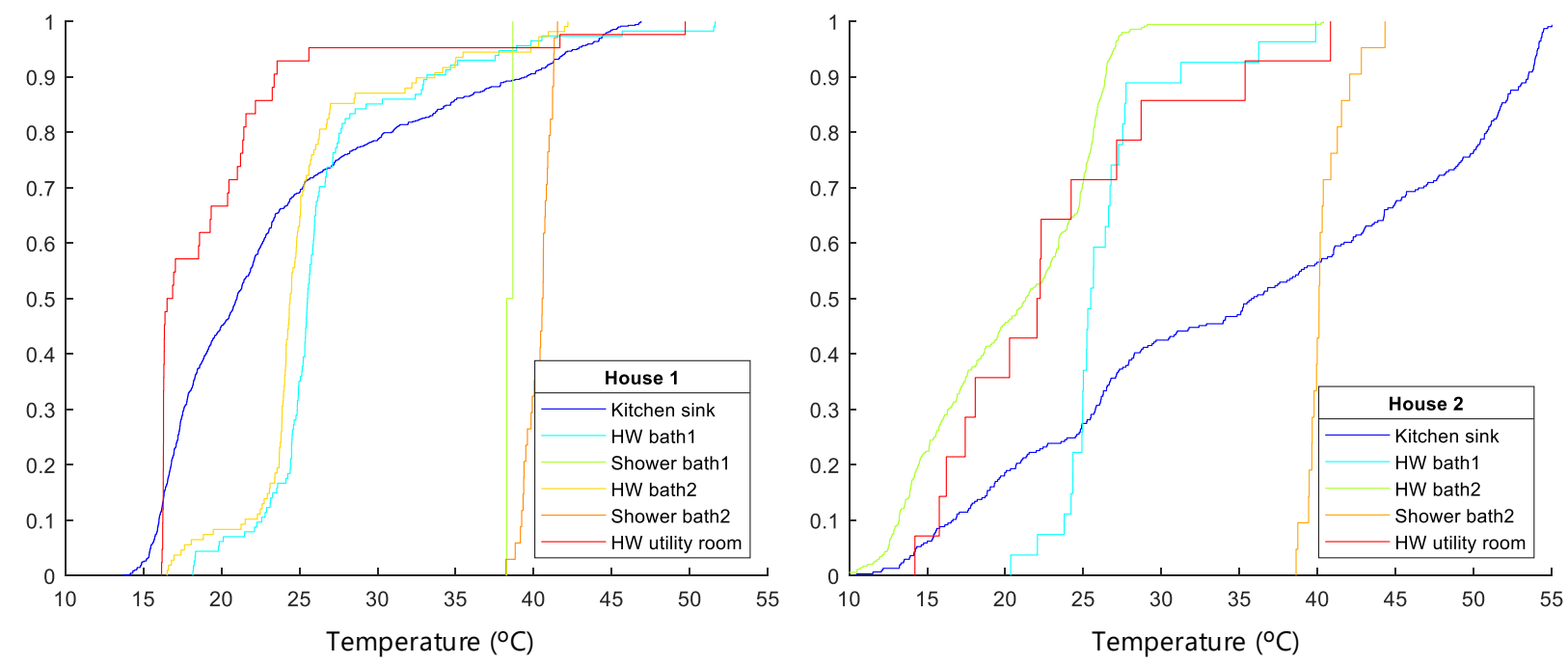

\begin{tabular}{r|cccc} 
Draw off point & Min $\left({ }^{\circ} \mathrm{C}\right)$ & Meadian $\left({ }^{\circ} \mathrm{C}\right)$ & Mean $\left({ }^{\circ} \mathrm{C}\right)$ & $\operatorname{Max}\left({ }^{\circ} \mathrm{C}\right)$ \\
\hline Kitchen sink & 13.7 & 21.0 & 24.5 & 46.9 \\
HW bath 1 & 18.2 & 25.5 & 26.3 & 51.6 \\
Shower bath 1 & 38.3 & 38.5 & 38.5 & 38.7 \\
HW bath 2 & 16.5 & 24.4 & 24.5 & 42.2 \\
Shower bath 2 & 38.2 & 40.6 & 40.3 & 41.5 \\
HW utility room & 16.2 & 16.7 & 26.9 & 49.7
\end{tabular}

\begin{tabular}{r|cccc} 
Draw off point & Min $\left({ }^{\circ} \mathrm{C}\right)$ & Meadian $\left({ }^{\circ} \mathrm{C}\right)$ & Mean $\left({ }^{\circ} \mathrm{C}\right)$ & $\operatorname{Max}\left({ }^{\circ} \mathrm{C}\right)$ \\
\hline Kitchen sink & 10.5 & 35.8 & 35.5 & 56.3 \\
HW bath 1 & 20.3 & 25.5 & 26.5 & 39.9 \\
HW bath 2 & 9.1 & 21.3 & 20.5 & 40.4 \\
Shower bath 2 & 38.6 & 40.1 & 40.4 & 44.3 \\
HW utility room & 14.2 & 22.1 & 23.2 & 40.8
\end{tabular}

Figure 4. Cumulated frequency of temperature of water draw events for all monitored taps. HW—hand washing point. 
The energy use for a water draw is directly related to its duration and temperature and is calculated using Equation (3). The energy use is not calculated at each second interval but per entire respective water taping. Therefore, the results illustrated in Figures 5 and 6 should only be considered as estimates. In both houses, the energy use during the shower event represents the most energy intense draw-off point. The energy use per shower event spans between $2300-8300 \mathrm{~kJ}$ and 4400-13,500 kJ for House 1 and House 2, respectively. The difference of factor 1.5-1.9 in energy use is the result of longer and higher temperature shower events in House 2; see Figures 3 and 4 . However, since the median and mean showering temperatures are of around $40{ }^{\circ} \mathrm{C}$ in both houses, we can conclude that the duration of showers is the main reason for this difference. The kitchen sink is a second water taping point where the energy use differs significantly between the two houses; cf. Figures 5 and 6. In this tap the temperature of the draw-off events influences the energy, the average difference is of factor 4 . The energy use in the hand washing water draw-off points is similar in both houses. In House 1, the energy use in both bathrooms is similar. The sink in the utility room has different purposes, as it is for dirtier and often time-consuming activities (e.g., washing shoes, pre-washing of clothes). In House 2, there is a clear intensity hierarchy of hand washing water taping points, with the sink in the bathroom close to the bedroom being the most energy intensive and with the sink in utility room least used. Figure 7 demonstrates showers and kitchen sinks are the most energy intense water taping points for hot water.
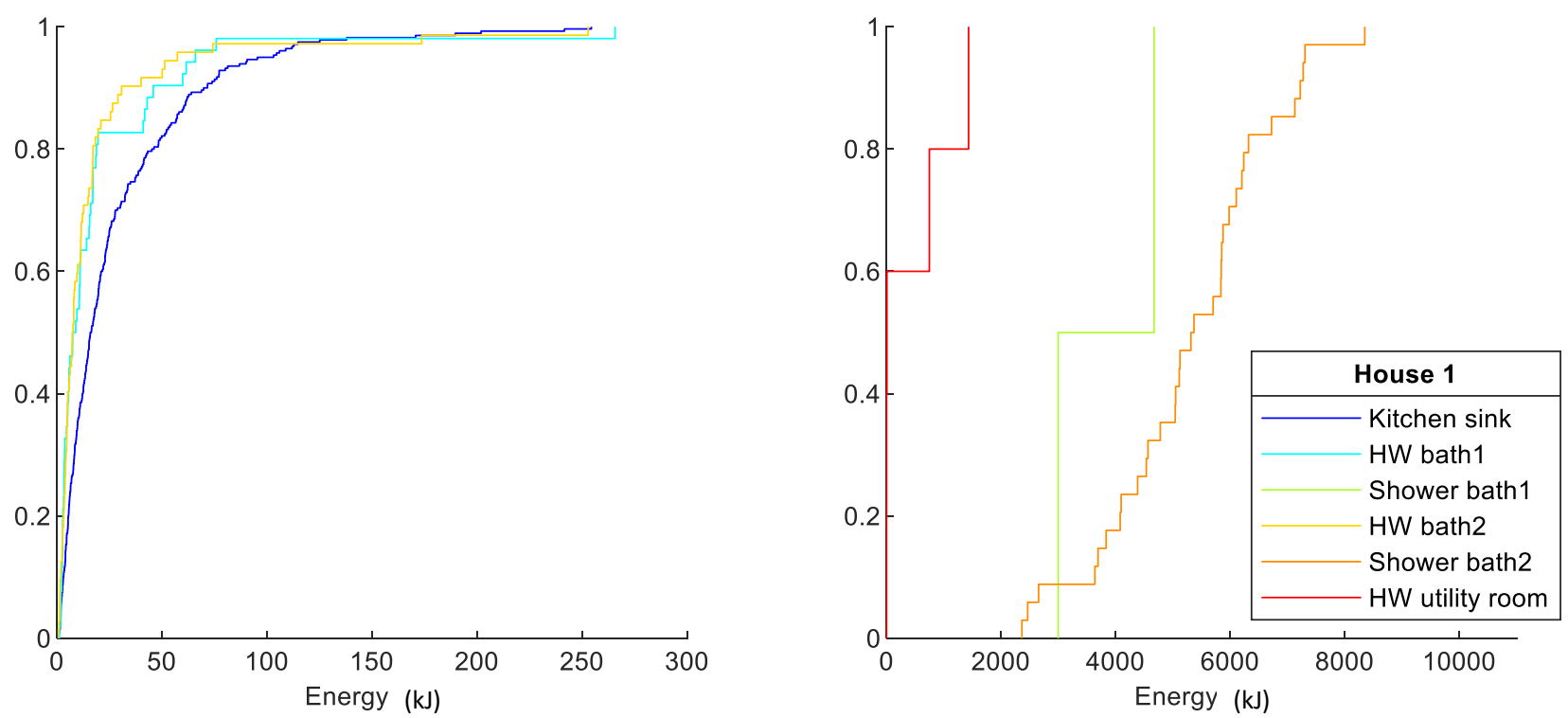

\begin{tabular}{r|cccc} 
Draw off point & Min $(\mathrm{kJ})$ & Median $(\mathrm{kJ})$ & Mean $(\mathrm{kJ})$ & Max $(\mathrm{kJ})$ \\
\hline Kitchen sink & 0.6 & 16.2 & 28.9 & 254.4 \\
HW bath 1 & 1.3 & 8.3 & 20.1 & 265.7 \\
Shower bath 1 & $2,996.8$ & $3,834.1$ & $3,834.1$ & $4,671.4$ \\
HW bath 2 & 0.8 & 7.6 & 17.7 & 252.9 \\
Shower bath 2 & $2,362.9$ & $5,339.6$ & $5,294.0$ & $8,345.8$ \\
HW utility room & 1.4 & 8.3 & 438.6 & $1,432.8$
\end{tabular}

Figure 5. Cumulated frequency of the estimated energy use for all water draw events in House 1. 

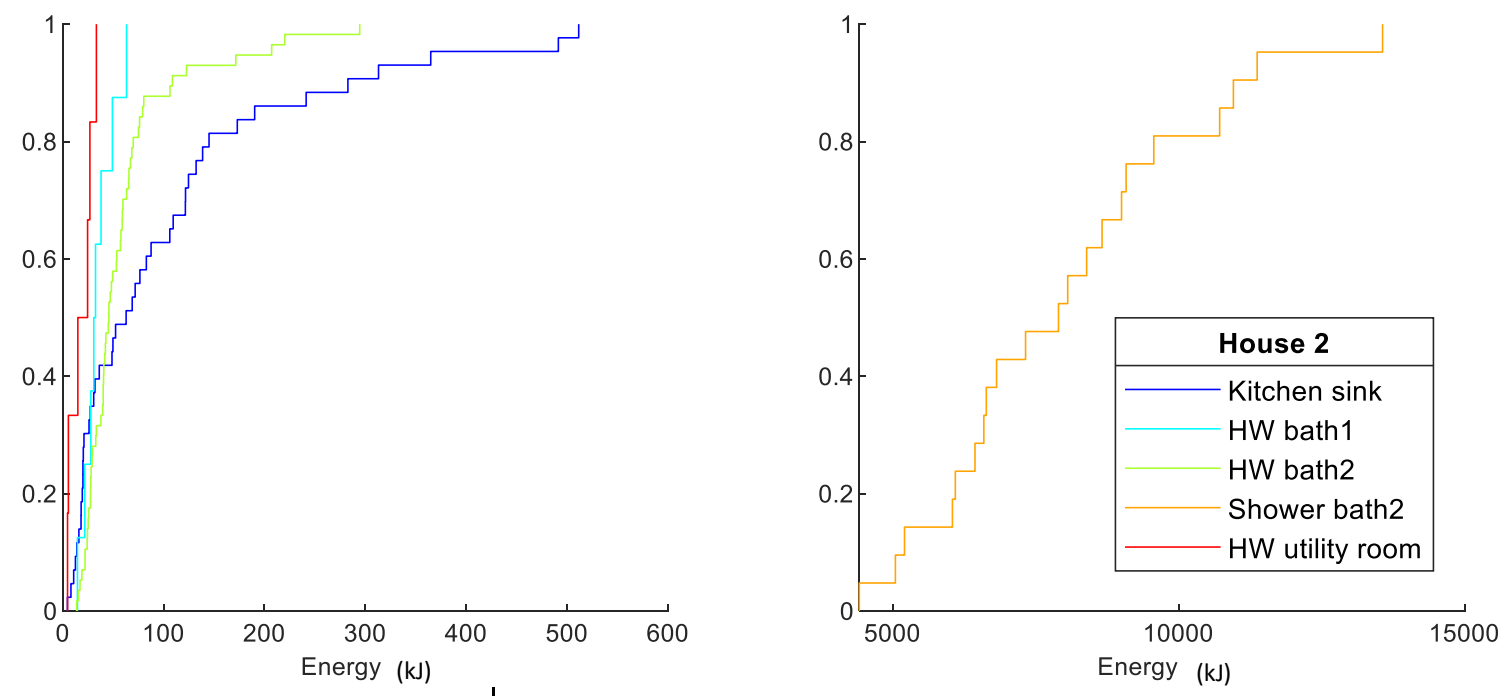

\begin{tabular}{r|cccc} 
Draw off point & Min $(\mathrm{kJ})$ & Meadian $(\mathrm{kJ})$ & Mean $(\mathrm{kJ})$ & Max $(\mathrm{kJ})$ \\
\hline Kitchen sink & 4.7 & 62.9 & 105.3 & 511.6 \\
HW bath 1 & 14.6 & 31.7 & 34.8 & 63.3 \\
HW bath 2 & 13.9 & 45.7 & 60.3 & 294.5 \\
Shower bath 2 & $4,417.2$ & $7,900.1$ & $7,996.1$ & $13,567.5$ \\
HW utility room & 4.8 & 19.8 & 18.4 & 33.4
\end{tabular}

Figure 6. Cumulated frequency of the estimated energy use for all water draw events in House 2.
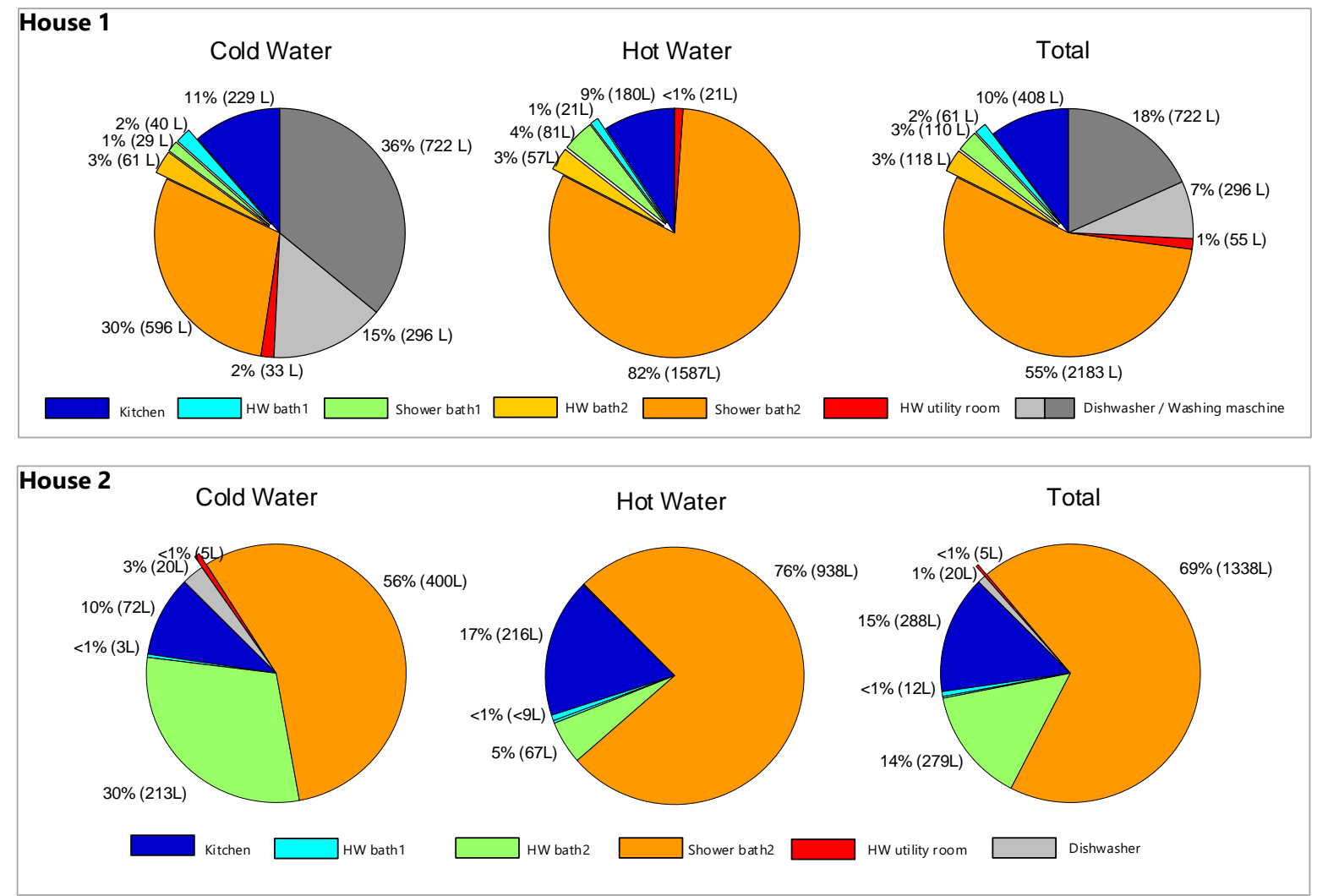

Figure 7. Distribution of the cold, hot and total water consumption between the taps in House 1 (top) and House 2 (bottom) during the monitoring period. 


\subsection{Household Daily Profiles}

\subsubsection{Profiles for Selected Days}

This part describes the daily water load profiles in each house for specific days selected from monitoring period. A weekday and a weekend day are selected from monitoring period in order to visualize the exact time of use of specific draw-off points in the monitored households (i.e., House 1 is a family of 2 adults +2 kids, and House 2 is a family of 2 adults). The water use profiles are presented for 1-s resolution in Figures 8 and 9.

\section{Weekday (Thursday)}
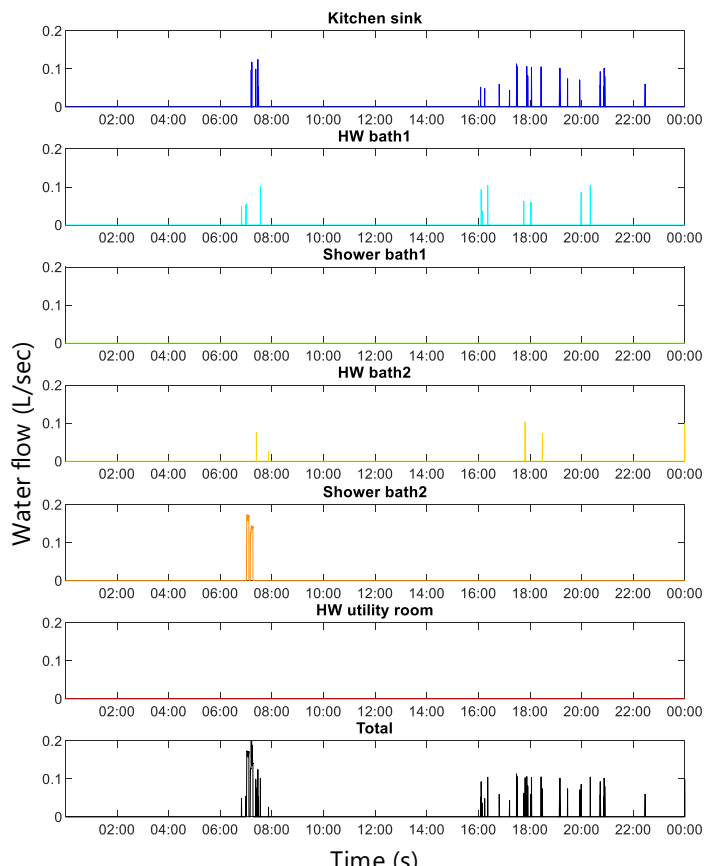

Weekend day (Saturday)
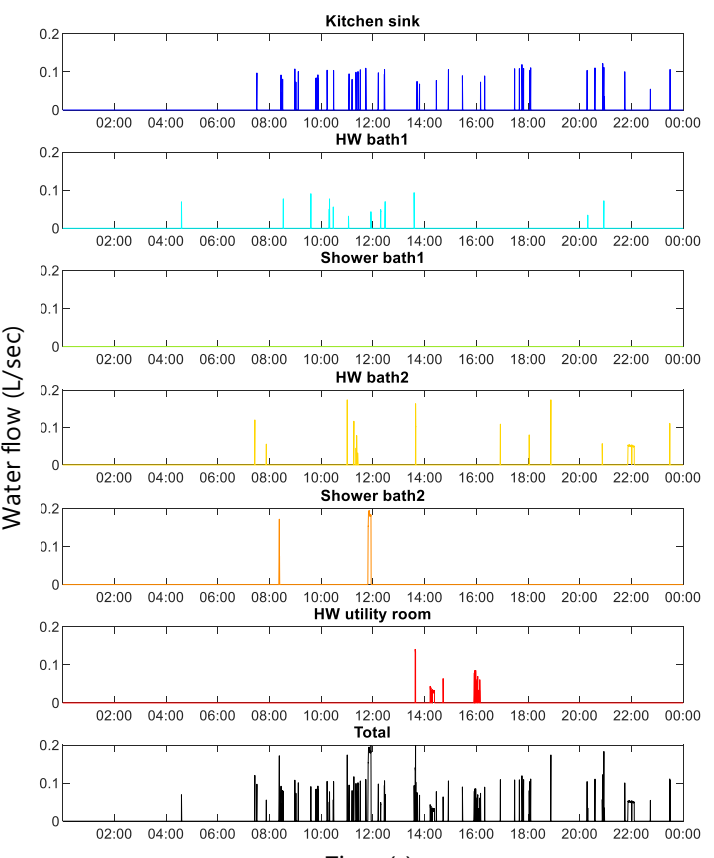

Time (s)

Figure 8. Diurnal 1-s water use in draw-off points in House 1 for weekday-20 September 2018 and weekend day22 September 2018.

Weekday (Thursday)

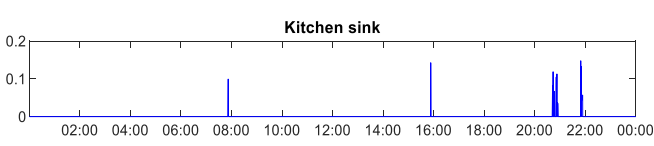

HW bath1
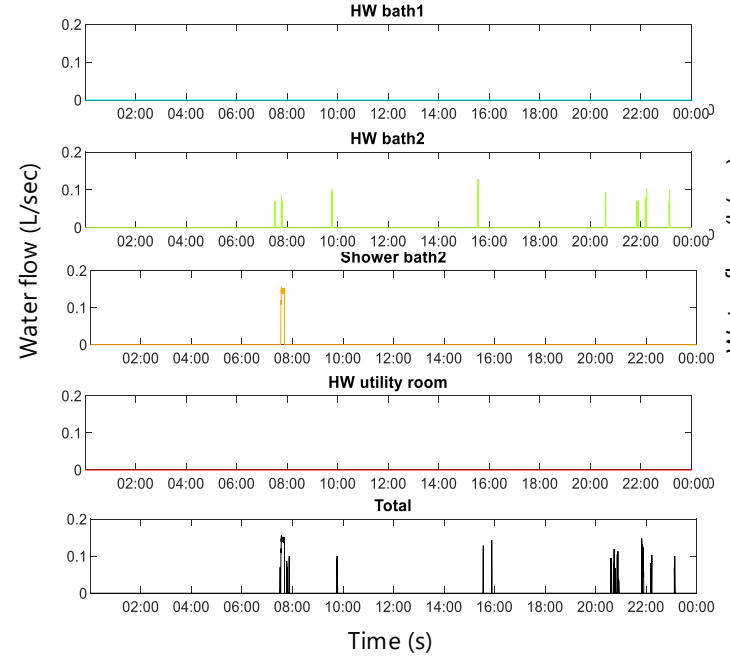

Weekend day (Sunday)
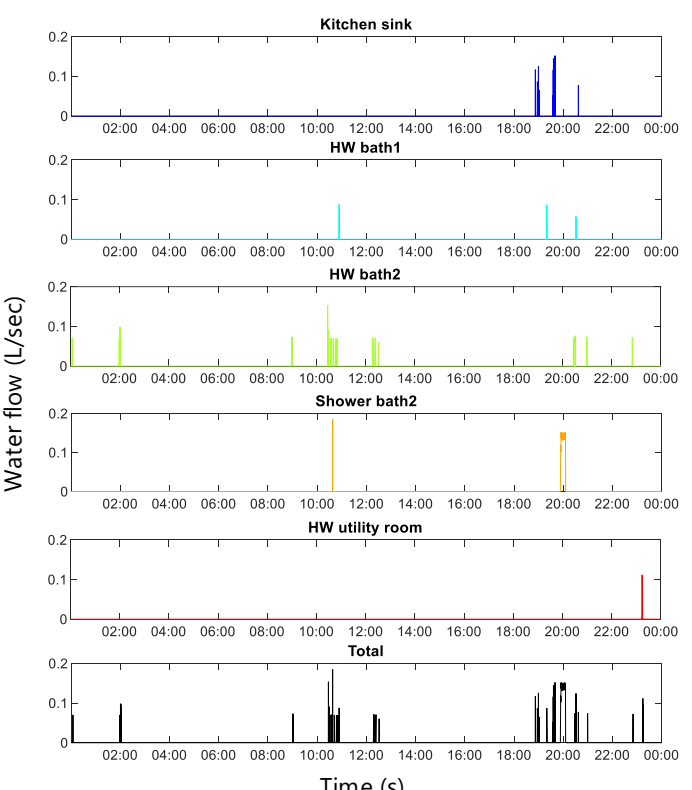

Figure 9. Diurnal 1-s water use in draw-off points in House 2 for a weekday—4 April 2019 and weekend day-7 April 2019. 
The spatial and temporal distribution of hot water usage is depicted in Figures 8 and 9 for selected days. In both houses, the shower is the most hot water intense draw-off points. The use of sinks in the houses has a dominating impact on daily profiles during short but frequent events in the afternoons. The showers in both houses are correlated with either wake-up or go-to-bed practices, which supports the thesis that showering practice is often associated with another action and is the preparation or end phase of a sequence of actions [7]. The use of kitchen sink is correlated with mealtime (i.e., breakfast 6:00 to 8:00 a.m., lunch 11:00 to 12:00 a.m., and dinner 6:00 to 8:00 p.m.). The use of the remaining draw-off points is more irregular and, therefore, difficult to correlate with other everyday practices.

\subsubsection{Mean Daily Water Profiles}

This part describes the mean daily water load profiles for weekdays and weekend. They are created in order to visualize the change of hot water practice and the change of hot water demand during a 24-h period. Figures 10 and 11 present the draw profiles in 1-s and 1-h resolution for House 1 and Figures 12 and 13 in House 2.

On weekdays, peaks occur from 6:30:00 to 7:00 a.m. due to morning shower routine. Thereafter, between 8:00 a.m. to 4:00 p.m., the consumption is low and uniformly distributed during most of the weekdays. Evening (i.e., between 6:00 to 8:00 p.m.) water draws are frequent but short and do not overlap; therefore, the consumption is more evenly distributed and without high peaks. The weekday mean water consumption is $169 \mathrm{~L}$ and in particular for hot water it is $92 \mathrm{~L}$. Friday profile is different for other weekdays due to the fact that one of family members works part-time and is home on Fridays. Therefore, in order to not overshadow the remaining weekdays, the Friday load profile is not shown in Figure 10. Weekend events are shifted forward with approximately $3 \mathrm{~h}$. Morning peak is lower but longer. The weekend mean water consumption is $181 \mathrm{~L}$ and in particular for hot water it is $94 \mathrm{~L}$. In general, water consumption during weekends is higher than for weekdays, and evening peak is more evident. Moreover, the morning peaks observed in House 1, and with the 2- to 3-h shift forward, showed the weekend water draw-off events resemble tendencies observed in Reference [18]. Ahmed et al. also observed that evening peaks for weekdays are lower than for mornings, and weekend morning peak and evening peak are more similar to each other.
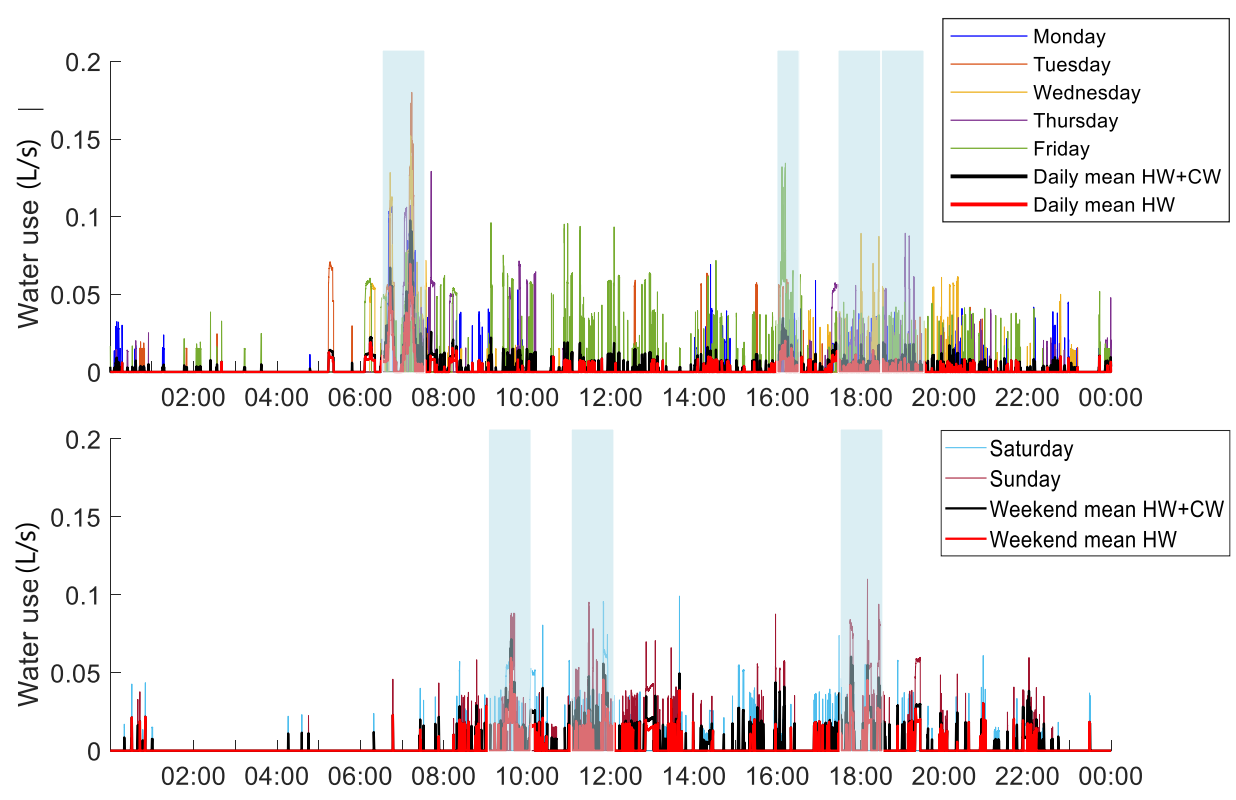

Figure 10. Diurnal 1-s mean water use in House 1 for weekdays and weekends. 


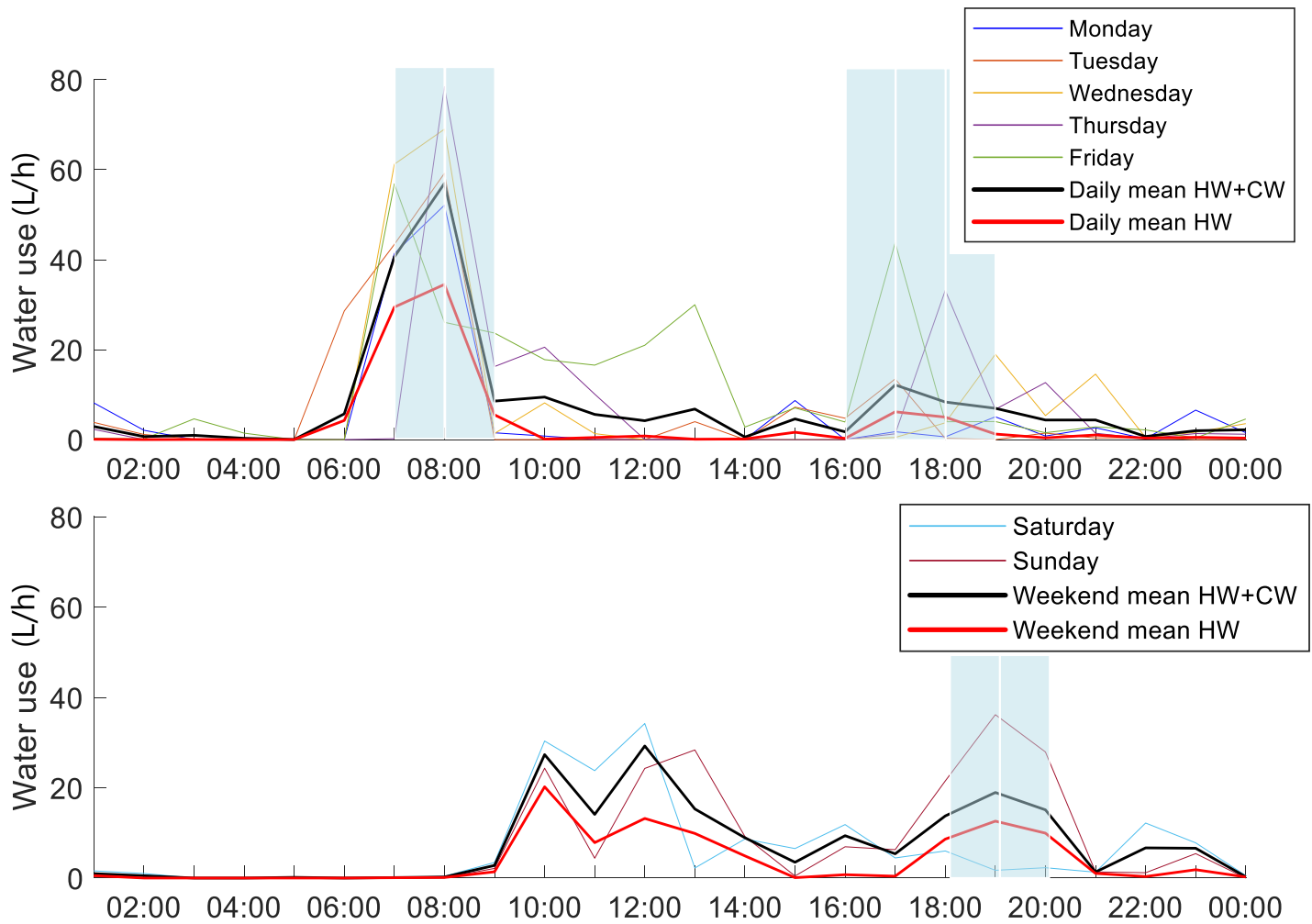

Figure 11. Diurnal hourly mean water use in House 1 for weekdays and weekends.
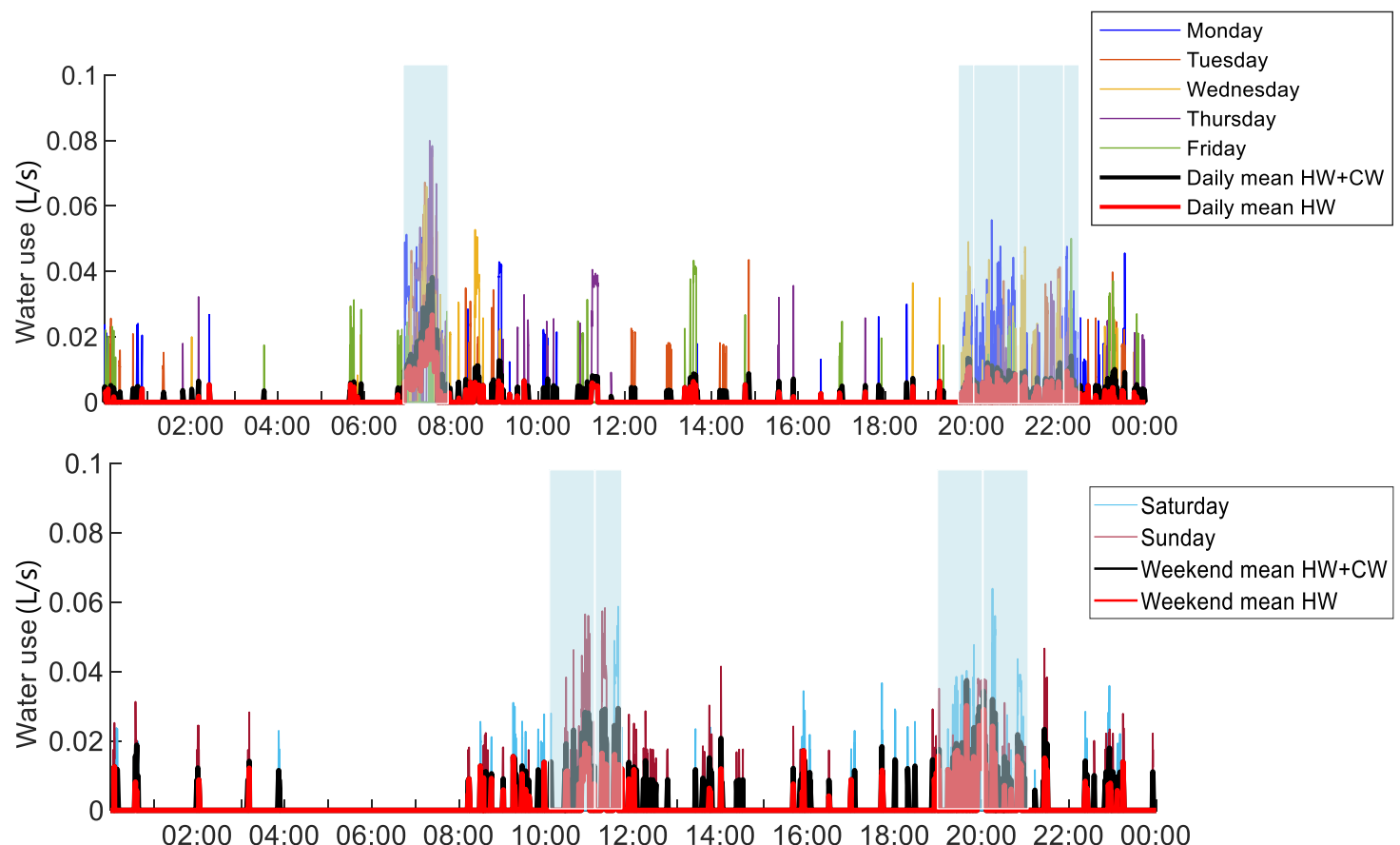

Figure 12. Diurnal 1-s mean water use in House 2 for weekdays and weekends. 


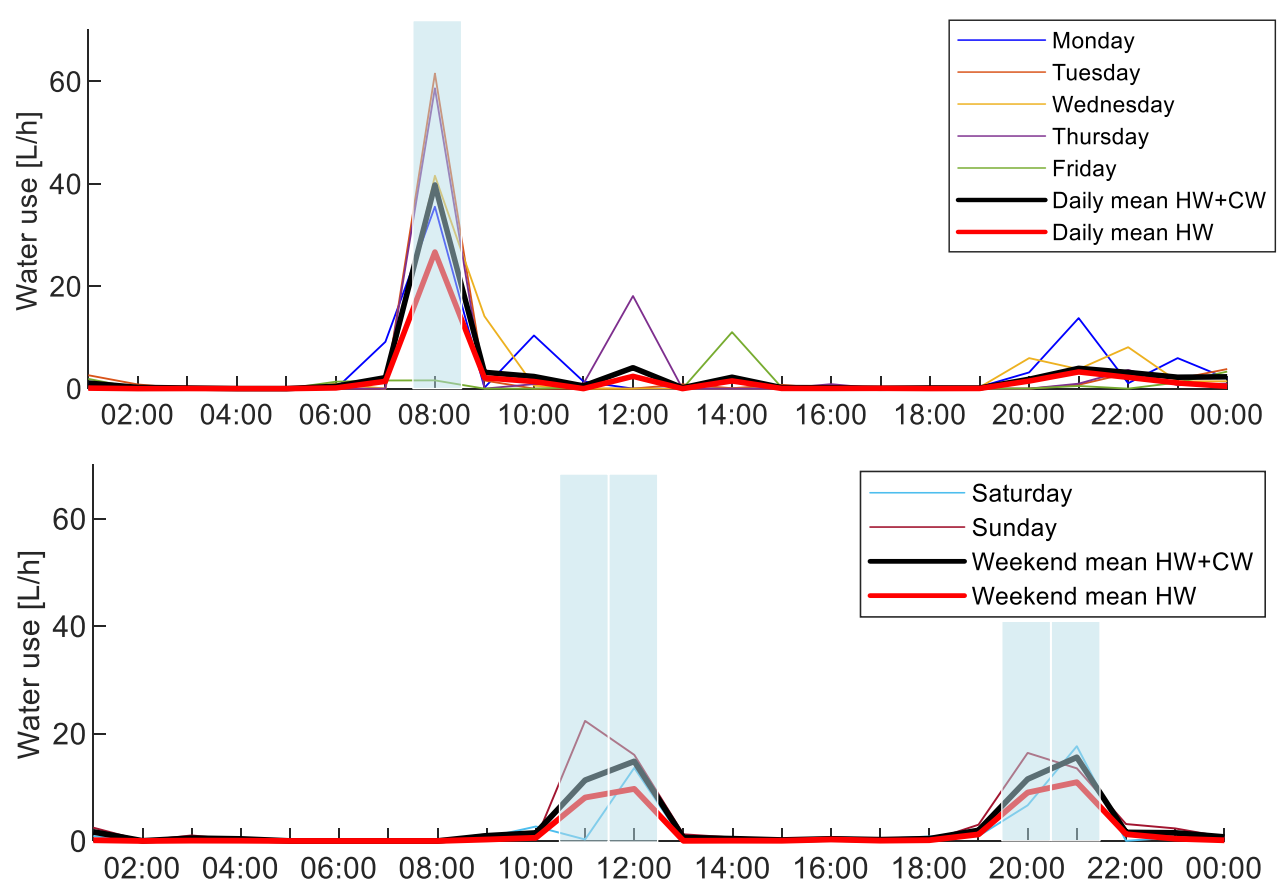

Figure 13. Diurnal hourly mean water use in House 2 for weekdays and weekends.

In House 2, all weekday profiles are very similar to each other, with a clear morning peak between 7:00 to 8:00 a.m. (i.e., morning shower routine). Afterwards, there are almost no water tapings detected until evening hours when occupants return from work and begin to use domestic water. Visible dissimilarities on one Monday, Thursday, and Friday are due to Easter holiday and family being at home these days. Weekend profiles are characterized by two peaks, morning and evening peak. In between, before and after peaks, there are no water taping events detected. The weekday mean water consumption is $71 \mathrm{~L}$, and, in particular, for hot water it is $44 \mathrm{~L}$. Weekend morning peak is shifted forward in time compared to weekdays till between 10:00 to 12:00 a.m. The weekend mean water consumption is $66 \mathrm{~L}$, and, in particular, for hot water it is $42 \mathrm{~L}$.

It can also be concluded that, although hourly presentation of results is easier to read, this has some consequences. For example, for 1-s data, the morning peak is between 6:30 to 7:00 a.m., and, for 1-h data morning peak, it is between 6:00 to 8:00 a.m. The monitoring frequency of $1 \mathrm{~s}$ is essential to collect data on water taping profiles, but it is concluded that presentation of results at that high resolution can make the reading of the results more difficult.

\section{Discussion}

By comparing the measured DHW use in the monitored houses to Danish compliance design values from Danish building regulations in [11] Table 4, it is clear that compliance design value overestimates the use of DHW by 1.5 and 2.5 for House 1 and House 2, respectively. The DHW consumption of $250 \mathrm{~L} / \mathrm{m}^{2}$ per year for residential buildings was set in 2006 when the first Danish compliance calculation tool "Be06" was launched and, since then, has not been chanced.

Table 4. DHW usage in monitored houses and Danish compliance design values.

\begin{tabular}{ccc}
\hline Case & Daily Consumption (L/day) & $\begin{array}{c}\text { Specific Consumption } \\
\left(\mathbf{L} / \mathbf{m}^{2} \text { per year) }\right.\end{array}$ \\
\hline House 1 & 88.5 & 166 \\
House 2 & 44 & 100 \\
Compliance design value & 164 & 250 (max $60 \mathrm{~m}^{3}$ per year) \\
\hline
\end{tabular}


Moreover, reported measured results indicate a strong correlation between DHW consumption, number of occupants and their daily activities. The presented results, although valid for only two households, put into question the correctness of the current approach for energy compliance calculations and enclosure of energy use for DHW. The difference of factor 1.5 and 2.5 between the theoretical and actual energy use is one of the reasons for the presence of the energy performance gap in the building sector. In the buildings where only the total the energy use for heating including the energy use for DHW and space heating is known, this discrepancy could significantly influence the energy evaluation of the building and cause erroneous conclusions about faulty operation of the building or necessity for envelope thermal renovation. The DHW load profile depends strongly on the number of occupants and their daily activities. Thus, it could be questioned why DHW is not considered in compliance energy frame calculation similarly to appliances or artificial lighting. These systems in residential buildings are operated individually by occupants and, therefore, are not included in compliance frame calculations. Therefore, the recommendations are to (a) consider the energy use for DHW separately and not as part of energy compliance calculations; (b) not correlate the DHW usage with the building area, since our living practices and floor area per person has changed significantly since 1990; and (c) evaluate the DHW production and distribution efficiency and eventual losses for individual design solution, which have different performances [4].

Conducted and presented in this paper, work indicates need for the following future work:

a. The most energy consuming taps are in both houses farthest from the hot water production point. The future work should focus on investigation of energy loss in the distribution of the hot water system. Spatial distribution of draw-off points and spatial DHW energy loss requires better understanding in order to be more optimally incorporated in the design phase.

b. Registered temperatures of DHW at hand wash events are, for most of the time, rather low, indicating that users do not wait for hot water and accept temperature as it is provided. Influence of the daily profile characteristics: day with many short water tapings versus day with few long draws should be deeper analyzed with respect to the DHW heat exchanger performance.

\section{Conclusions}

This paper presents detailed measurements of spatial and temporal comfort of hot water in two detached single-family houses. The results confirmed that domestic water practices and consumption are strongly correlated with the number of occupants per household and with their daily routines inside and outside the homes. Both of the houses have DHW morning and evening peaks. House 1, occupied by a family with small children, showed 1.6 times higher domestic water consumption than House 2, which is occupied by only two adults. Moreover, daily routines, wake-up time, and professional and sport activities have significant influence on frequency, intensity, and distribution of activation of different draw-off points. Moreover, working at home is also represented by elevated water consumption profiles.

The observed DHW patterns during weekdays and weekends are in line with the results from other field tests. Weekdays are characterized by one strong morning peak, while weekends are characterized by two more mild peaks, one in the mornings and one in the evenings. The peaks can be assigned mainly to showering events, which are responsible for $70 \%$ to $80 \%$ of DHW use, as it is illustrated in Figure 8 .

Comfort of domestic water is, in general, not well investigated in the reported monitoring campaigns. It is often wrongly assumed that DHW has the constant temperature of $55^{\circ} \mathrm{C}$. This might be true at the production substation, but, as the results show, at the draw-off points, the temperature of $55^{\circ} \mathrm{C}$ is never asked by the occupants, not even in the kitchen sink. As can be observed, spatial distribution of the domestic water temperature differentiates depending on the function of the draw-off point. Shower units on average represent demand for highest temperatures $35.5^{\circ} \mathrm{C}$ to $40.4^{\circ} \mathrm{C}$. Hand washing operates on 
average at $20.5^{\circ} \mathrm{C}$ to $26.5^{\circ} \mathrm{C}$ and sink in the utility room at $23^{\circ} \mathrm{C}$ to $26{ }^{\circ} \mathrm{C}$. Observed mean temperature in the kitchen sink is significantly different in the monitored buildings (i.e., House $1-24.5^{\circ} \mathrm{C}$; House $2-35.5^{\circ} \mathrm{C}$ ). The results of this study confirm that requirements, as stated in Reference [4], that DHW temperatures in the installations must not drop below $50{ }^{\circ} \mathrm{C}$ are primarily, if not solely, required in order to avoid bacteria growth, primarily Legionella growth, and not due to comfort requirements.

Similar to other past studies [30], showering events are the longest of all water taping events and are responsible for majority of energy use for DHW preparation. The mean shower duration for three monitored showers is between 3.5 and $8.0 \mathrm{~min}$, giving the best possibility out of all draw-off points for heat recovery installation as presented in several past research studies [31-33].

Author Contributions: Conceptualization, A.M.-P., R.L.J., J.S.J. and S.S.K.; methodology, A.M.-P., R.L.J., J.S.J. and S.S.K.; formal analysis, J.S.J. and S.S.K.; investigation, J.S.J. and S.S.K.; data curation, J.S.J. and S.S.K.; writing-original draft preparation, A.M.-P. and M.P.; writing-review and editing, R.L.J. and O.K.L.; visualization, A.M.-P.; supervision, A.M.-P. and R.L.J. All authors have read and agreed to the published version of the manuscript.

Funding: This research received no external funding.

Institutional Review Board Statement: Ethical review and approval were waived for this study, due to the fact the consent has already been collected within project "Bolig 2020 med lavt energiforbrug og høj brugerkomfort" (EUDP 64015-0640).

Informed Consent Statement: Informed consent was obtained from all subjects involved in the study.

Data Availability Statement: The data presented in this study are available on request from the corresponding author. The data are not publicly available due to project restrictions.

Acknowledgments: This work was supported by the InterHUB project, funded by Aalborg University' strategic funding for interdisciplinary research. InterHUB: Intermittent energy-Integrating Households, Utilities and Buildings. For more information on the project see: www.interhub.aau.dk.

Conflicts of Interest: The authors declare no conflict of interest.

\section{References}

1. IEA. Energy Efficiency 2020; IEA: Paris, France, 2020.

2. EN ISO 52000-1:2017 Energy Performance of Buildings—Overarching EPB Assessment_Part 1: General Framework and Procedures; CEN-CENELEC Management Centre: Brussels, Belgium, 2017.

3. Danish Energy Agency Annual Energy Statistics 2019. Available online: https://ens.dk/en/our-services/statistics-data-keyfigures-and-energy-maps/annual-and-monthly-statistics (accessed on 20 May 2021).

4. Pomianowski, M.Z.; Johra, H.; Marszal-Pomianowska, A.; Zhang, C. Sustainable and energy-efficient domestic hot water systems: A review. Renew. Sustain. Energy Rev. 2020, 128, 1-18. [CrossRef]

5. Widén, J.; Lundh, M.; Vassileva, I.; Dahlquist, E.; Ellegård, K.; Wäckelgård, E. Constructing load profiles for household electricity and hot water from time-use data-Modelling approach and validation. Energy Build. 2009, 41, 753-768. [CrossRef]

6. Fuentes, E.; Arce, L.; Salom, J. A review of domestic hot water consumption profiles for application in systems and buildings energy performance analysis. Renew. Sustain. Energy Rev. 2018, 81, 1530-1547. [CrossRef]

7. Gram-Hanssen, K.; Christensen, T.; Madsen, L.; do Carmo, C. Sequence of practices in personal and societal rhythms-Showering as a case. Time Soc. 2018, in press. [CrossRef]

8. Marszal-Pomianowska, A.; Zhang, C.; Pomianowski, M.; Heiselberg, P.; Gram-Hanssen, K.; Rhiger Hansen, A. Simple methodology to estimate the mean hourly and the daily profiles of domestic hot water demand from hourly total heating readings. Energy Build. 2019, 184, 53-64. [CrossRef]

9. Bøhm, B.; Schrøder, F.; Bergsøe, N.C. SBi:2009:10 Varmt Brugsvand-Måling Af Forbrug og Varmetab fra Cirkulationsledninger [Domestic Hot Water-Measuring Consumption and Heat Loss from Circulation Pipelines]. Statens Byggeforskningsinstitut, Hørsholm. 2009. Available online: https:/ / sbi.dk/Assets/Varmt-Brugsvand/sbi-2009-10-pdf.pdf (accessed on 29 May 2021).

10. Chao, P.R.; Umapathi, S.; Saman, W. Water consumption characteristics at a sustainable residential development with rainwatersourced hot water supply. J. Clean. Prod. 2015, 109, 190-202. [CrossRef]

11. Aggerholm, S. SBi-Anvisning 213 Bygningers Energibehov. Statens Byggeforskningsinstitut, Hørsholm. 2018. Available online: https://sbi.dk/anvisninger/Pages/213-Bygningers-energibehov-6.aspx (accessed on 29 May 2021).

12. Becker, B.R.; Stogsdill, K.E. Development of a hot water use data base. In Proceedings of the ASHRAE Transactions, St. Louis, MO, USA, 9-13 June 1990; 1990; pp. 422-427. 
13. Papakostas, K.T.; Papageorgiou, N.E.; Sotiropoulos, B.A. Residential hot water use patterns in Greece. Sol. Energy 1995, 54, 369-374. [CrossRef]

14. Bøhm, B. Production and distribution of domestic hot water in selected Danish apartment buildings and institutions. Analysis of consumption, energy efficiency and the significance for energy design requirements of buildings. Energy Convers. Manag. 2013, 67, 152-159. [CrossRef]

15. Thomas, M.; Hayden, A.C.S.; Ghiricociu, O.; Cane, R.L.D.; Gagnon, R. A new study of hot-water use in Canada. ASHRAE Trans. 2011, 117, 673-682.

16. Ahmed, K.; Pylsy, P.; Kurnitski, J. Monthly domestic hot water profiles for energy calculation in Finnish apartment buildings. Energy Build. 2015, 97, 77-85. [CrossRef]

17. Edwards, S.; Beausoleil-Morrison, I.; Laperrière, A. Representative hot water draw profiles at high temporal resolution for simulating the performance of solar thermal systems. Sol. Energy 2015, 111, 43-52. [CrossRef]

18. Ahmed, K.; Pylsy, P.; Kurnitski, J. Hourly consumption profiles of domestic hot water for different occupant groups in dwellings. Sol. Energy 2016, 137, 516-530. [CrossRef]

19. de Santiago, J.; Rodriguez-Vialon, O.; Sicre, B. The generation of domestic hot water load profiles in Swiss residential buildings through statistical predictions. Energy Build. 2017, 141, 341-348. [CrossRef]

20. Marszal-Pomianowska, A.; Valeva, B.; Georgieva, V.; Larsen, O.K.; Jensen, R.L.; Zhang, C. High resolution measuring system for domestic hot water consumption. Development and field test. Energy Procedia 2019, 158, 2859-2864. [CrossRef]

21. Beal, C.D.; Bertone, E.; Stewart, R.A. Evaluating the energy and carbon reductions resulting from resource-efficient household stock. Energy Build. 2012, 55, 422-432. [CrossRef]

22. Beal, C.D.; Stewart, R.A.; Fielding, K. A novel mixed method smart metering approach to reconciling differences between perceived and actual residential end use water consumption. J. Clean. Prod. 2013, 60, 116-128. [CrossRef]

23. Kenway, S.J.; Scheidegger, R.; Larsen, T.A.; Lant, P.; Bader, H.P. Water-related energy in households: A model designed to understand the current state and simulate possible measures. Energy Build. 2013, 58, 378-389. [CrossRef]

24. Binks, A.N.; Kenway, S.J.; Lant, P.A.; Head, B.W. Understanding Australian household water-related energy use and identifying physical and human characteristics of major end uses. J. Clean. Prod. 2016, 135, 892-906. [CrossRef]

25. Bertrand, A.; Mastrucci, A.; Schüler, N.; Aggoune, R.; Maréchal, F. Characterisation of domestic hot water end-uses for integrated urban thermal energy assessment and optimisation. Appl. Energy 2017, 186, 152-166. [CrossRef]

26. Fischer, D.; Wolf, T.; Scherer, J.; Wille-Haussmann, B. A stochastic bottom-up model for space heating and domestic hot water load profiles for German households. Energy Build. 2016, 124, 120-128. [CrossRef]

27. HusCampagniet. Available online: https://www.huscompagniet.dk/ (accessed on 29 May 2021).

28. Huba Control. Available online: https:/ /www.hubacontrol.com/en/products/vortex-flow-sensor (accessed on 29 May 2021).

29. Katronic. Available online: https://www.katronic.com/fileadmin/katronic/downloads/datasheets/DS_KF100_V41EN_1504 .pdf (accessed on 29 May 2021).

30. Prado, R.T.A.; Gonçalves, O.M. Water heating through electric shower and energy demand. Energy Build. 1998, 29, 77-82. [CrossRef]

31. Wong, L.T.; Mui, K.W.; Guan, Y. Shower water heat recovery in high-rise residential buildings of Hong Kong. Appl. Energy 2010, 87, 703-709. [CrossRef]

32. McNabola, A.; Shields, K. Efficient drain water heat recovery in horizontal domestic shower drains. Energy Build. 2013, 59, 44-49. [CrossRef]

33. Ip, K.; She, K. Waste heat recovery from showers: Case study of a university sport facility in the UK. In Proceedings of the Water Efficiency Conference 2016, Coventry, UK, 7-9 September 2016. 